\title{
Effects of spatial-temporal land cover distribution on gross primary production and net primary production in Schleswig-Holstein, northern Germany
}

Liwei $M a^{1,2^{*}}$

\begin{abstract}
Background: Annual total Gross Primary Production (GPP) and Net Primary Production (NPP) and the annual total stored GPP and NPP are tightly coupled to land cover distributions because the distinct vegetation conditions of different land cover classes strongly affect GPP and NPP. Spatial and statistical analysis tools using Geographic Information Systems (GIS) were used to investigate the spatial distribution of each land cover class and the GPP and NPP based on the CORINE land cover classification in the federal state, Schleswig-Holstein, Germany for the years 2000, 2006 and 2012.
\end{abstract}

Results: "Non-irrigated arable land" and "pastures" were the dominant land cover classes. Because of their large area, "non-irrigated arable land" and "pastures" had higher annual total stored GPP and NPP values than the other land cover classes. Annual total GPP and NPP hotspots were concentrated in the central-western part of Schleswig-Holstein. Cold spots were mainly located in the western and eastern Schleswig-Holstein. The distributions of the annual total GPP and NPP hotspots and cold spots were primarily determined by land cover and land cover changes among the investigated years. The average annual total NPP/GPP ratios were 0.5647, 0.5350 and 0.5573 in the years 2000, 2006 and 2012, respectively. The calculated respiration in 2006 was the highest, followed by those in 2012 and 2000.

Conclusions: The land cover classes with high-ability of carbon stocks in 2000, 2006 and 2012 in Schleswig-Holstein were identified in this study. Furthermore, it is recommendable to enhance the annual total GPP and NPP and the annual total stored GPP and NPP in Schleswig-Holstein by replacing the land cover classes showing low carbon stock capabilities with the classes showing high abilities for the purpose of increasing greenhouse gas fixation.

Keywords: Carbon stocks, Land cover, NPP/GPP, Calculated respiration, Hotspots and cold spots

\section{Highlights}

- Coordination of Information on the Environment (CORINE) land cover distributions are assessed.

\footnotetext{
24118 Kiel, Germany

*Correspondence: mickymlw@hotmail.com; maliwei@ibcas.ac.cn

${ }^{1}$ Department of Ecosystem Management, Institute for Natural Resource

Conservation, Christian-Albrechts-Universität Zu Kiel, Olshausenstr.75,

Full list of author information is available at the end of the article
- Land cover classes affect annual total Gross Primary Production (GPP) and Net Primary Production (NPP).

- Locations of the hotspots and cold spots for respiration and the NPP/GPP ratio are identified.

- Land cover planning can increase GPP and NPP.

(c) The Author(s) 2020. This article is licensed under a Creative Commons Attribution 4.0 International License, which permits use, sharing, adaptation, distribution and reproduction in any medium or format, as long as you give appropriate credit to the original author(s) and the source, provide a link to the Creative Commons licence, and indicate if changes were made. The images or other third party material in this article are included in the article's Creative Commons licence, unless indicated otherwise in a credit line to the material. If material is not included in the article's Creative Commons licence and your intended use is not permitted by statutory regulation or exceeds the permitted use, you will need to obtain permission directly from the copyright holder. To view a copy of this licence, visit http://creativeco mmons.org/licenses/by/4.0/. The Creative Commons Public Domain Dedication waiver (http://creativecommons.org/publicdomain/ zero/1.0/) applies to the data made available in this article, unless otherwise stated in a credit line to the data. 


\section{Background}

Land cover is a focal point for mapping and assessing carbon stocks [1-4] because land cover is a major driver of the distribution and function of carbon stocks, such as Gross Primary Production (GPP) and Net Primary Production (NPP). In addition, habitat fragmentation and species loss are caused by land cover and land use changes [5]. Threats to biodiversity and ecosystems are affected by land cover and land cover changes, and these threats could be minimized through better spatial planning [6]. Considering the land cover distribution is the basis for understanding the respective land cover situations and carbon stocks. The detected land cover patterns form a basic data source for interpretation and calculations to characterize the landscape potential of evaluating carbon stocks. Mapping and assessing land cover distributions are core units of the European Union (EU) biodiversity strategy [7]. Developing a primary data source for an European green infrastructure, resources to identify areas for ecosystem restoration, and a baseline for the goal of "no net loss of biodiversity and ecosystem services" are required EU-wide objectives [8, 9]. Socioeconomic factors are significant determinants of land cover distribution besides obvious affections to human society held by land cover $[10,11]$. It is prominent to have a trade-off between artificial activities and influences that result from land cover distribution.

Carbon stocks are strongly affected by the environment (e.g., water, nutrients illumination) via fluctuations in the carbon concentration due to the different environmental conditions that result from distinct surface landscape conditions. GPP and NPP are the beginning of the carbon cycle in ecosystems. GPP is defined as the total carbon assimilated through photosynthesis, indicating the capacity of plants to capture carbon and energy. NPP is the net carbon stored as new biomass in ecosystems [12, 13]. As the factors that measure efficiency of storing atmospheric carbon, the ratio between GPP and NPP (NPP/GPP) and the calculated respiration, which has been defined as GPP minus NPP, are the most primary important indicators for comparing the differences between GPP and NPP $[14,15]$. These indicators exhibit the abilities of ecosystems to affect carbon stocks and global climate regulation [16-18]. Calculating GPP and NPP based on land cover categories is because a land cover class can represent an ecosystem. Forest ecosystems are considered having higher annual total GPP and NPP than shrublands and croplands [19, 20], and the annual total GPP and NPP in grassland are variable because there are different grassland types [21]. In addition to the annual total GPP and NPP, the annual total stored GPP and NPP, which represent the carbon stocks in one area, vary depending on the research area [22]. In addition, the calculated respiration and the NPP/GPP ratio have been assumed to be correlated to land cover classes [23-25].

However, previous studies primarily considered the annual total GPP and NPP, the calculated respiration, the NPP/GPP ratio, and the annual total stored GPP and NPP in forests, grasslands and croplands [26-28], and some of them have been studied at the global scale [14, 29-31]. Although a large number of studies have been performed, there have been few studies on the annual total GPP and NPP, the calculated respiration, the NPP/GPP ratio, and the annual total stored GPP and NPP considering all land cover classes at regional scales. Schleswig-Holstein is an important German federal state that includes 32 out of 44 land cover classes in the CORINE land cover classification [32]. The land cover distributions and their effects on the annual total GPP and NPP, the calculated respiration, the NPP/GPP ratio, and the annual total stored GPP and NPP in different land cover classes in 2000, 2006 and 2012 can be entirely explained by the various land cover types and the continuous land cover changes among the 3 years. This study aims to provide building blocks for assessments at regional scales through a flexible method, and to ensure the EU member states support assessments in relation to the requirements for planning, agriculture, climate, water and nature policy by clarifying GPP and NPP based on the various land cover classes in Schleswig-Holstein, Germany. The objectives were to answer:

- How are different land cover classes distribute in 2000, 2006 and 2012 based on the CORINE land cover data set?

- What are the values of the annual total GPP and the annual total NPP in various land cover classes, and how do land cover classes influence the GPP and NPP distributions?

- What are the values of the respiration and the NPP/ GPP ratio in 2000, 2006 and 2012 based on the classification of the CORINE land cover, and where are the hotspots and cold spots for the respiration and the NPP/GPP ratio in Schleswig-Holstein for the years 2000, 2006 and 2012?

\section{Methods \\ Research areas}

Schleswig-Holstein (Fig. 1) is one of the 16 German federal states, locating on the northernmost national border. The state borders Denmark to the north and three German states to the south. It borders the North Sea to the west and the Baltic Sea to the east. The main landscapes are Marsch (marsh area), Geest (sandy area) and Hügelland (hill area). Alternating warmer and colder 


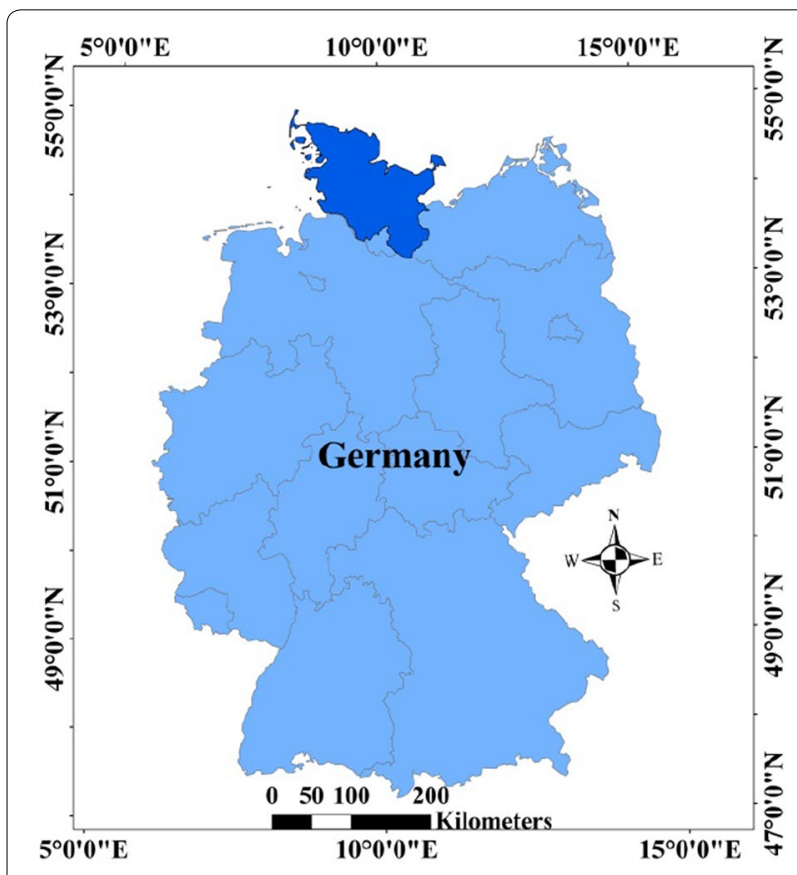

Fig. 1 States of Germany, the state in dark blue is Schleswig-Holstein

phases and the melting of glaciers in northern Germany during the Pleistocene and Holocene are the reasons for formation of landscape regions in Schleswig-Holstein [33]. There are three glaciation phases, including Saale-Elster-Weichsel, Saale and Elster moraines, in the Geest area. The Hügelland area is primarily composed of Weichsel moraines and the glacial series-Marsch, and they extended to the North Sea to form the Marsch area $[33,34]$.

\section{Data sources and methods \\ Data sources}

The CORINE land cover maps (Fig. 2) [35] are based on remote sensing data and were downloaded from the European Environmental Agency (EEA). They describe the primary land cover characteristics for whole Europe derived from long-term investigations and advanced technologies on data calibration and mapping [36, 37]. The CORINE land cover data contain an inventory of 44 (Level 3 of the CORINE Land Cover Classification) land cover classes, being available for the EU member states in 1990, 2000, 2006 and 2012 [38].

Maps of the German federal states and the borders of Schleswig-Holstein were downloaded from the Amtliches Topographisch-Kartographisches Informations-System [39]. The Moderate Resolution Imaging Spectroradiometer (MODIS) provided terrestrial satellite remote sensing images, aiming at observing parameters used for global change research that were related to ecosystem status assessment [40, 41]. GPP and NPP data were the prime components of the MOD17 products [42]. The data on the annual total GPP and the annual total NPP with $1 \mathrm{~km} \times 1 \mathrm{~km}$ grids of Schleswig-Holstein in 2000, 2006 and 2012 were retrieved from the database of MOD17A3 at the Numerical Terradynamic Simulation Group of the University of Montana [31].

\section{Methods}

Land cover distribution The CORINE land cover maps of Schleswig-Holstein for the years 2000, 2006 and 2012 with a resolution of $250 \mathrm{~m}$ were used to visualize the land cover distributions and to calculate percentage of the land cover classes using ArcGIS (the Geographic Information System). Vector data were used to calculate the area of each land cover class in Schleswig-Holstein.

Annual total GPP and annual total NPP classified by land cover The MODIS GPP and NPP Project [43] were the first satellite-driven data sets to monitor vegetation productivity at a global scale. The data set supported GPP and NPP maps containing the annual total GPP and NPP at the resolution of $1 \mathrm{~km}$ for all continents. Therefore, it was possible to derive GPP and NPP data for Schleswig-Holstein from MODIS 17 products for carbon cycle analysis in this study. However, GPP and NPP data were unavailable in artificial areas and water bodies, because there was little vegetation cover in artificial areas and no terrestrial vegetation in water bodies [44].

The annual total GPP maps with $1 \mathrm{~km} \times 1 \mathrm{~km}$ grids in 2000, 2006 and 2012, which were generated with ArcGIS 10.3, were used to visualize the GPP distributions in Schleswig-Holstein. The original GPP maps with $1 \mathrm{~km} \times 1 \mathrm{~km}$ grids were resampled into maps with $250 \mathrm{~m} \times 250 \mathrm{~m}$ grids to have the same resolution as the CORINE land cover maps. Then, the annual total GPP was computed based on the land cover classes with ArcGIS 10.3 by combining the annual total GPP maps and the CORINE land cover maps. Afterwards, for the target of calculating the annual total stored GPP and NPP (Mg C year $\left.{ }^{-1}\right)$, which were defined as the GPP stock in each land cover, the annual total stored GPP in a certain land cover (CLC area (ha)) were calculated by Eq. (1):

$$
\begin{aligned}
& \text { the annual total stored GPP } \\
& \quad=\text { the annual total GPP } \times C L C \text { area }
\end{aligned}
$$

Correlations among the annual total GPP, the land cover area and the annual total stored GPP based on the land cover classes were calculated using the $\mathrm{R}$ software [45]. 

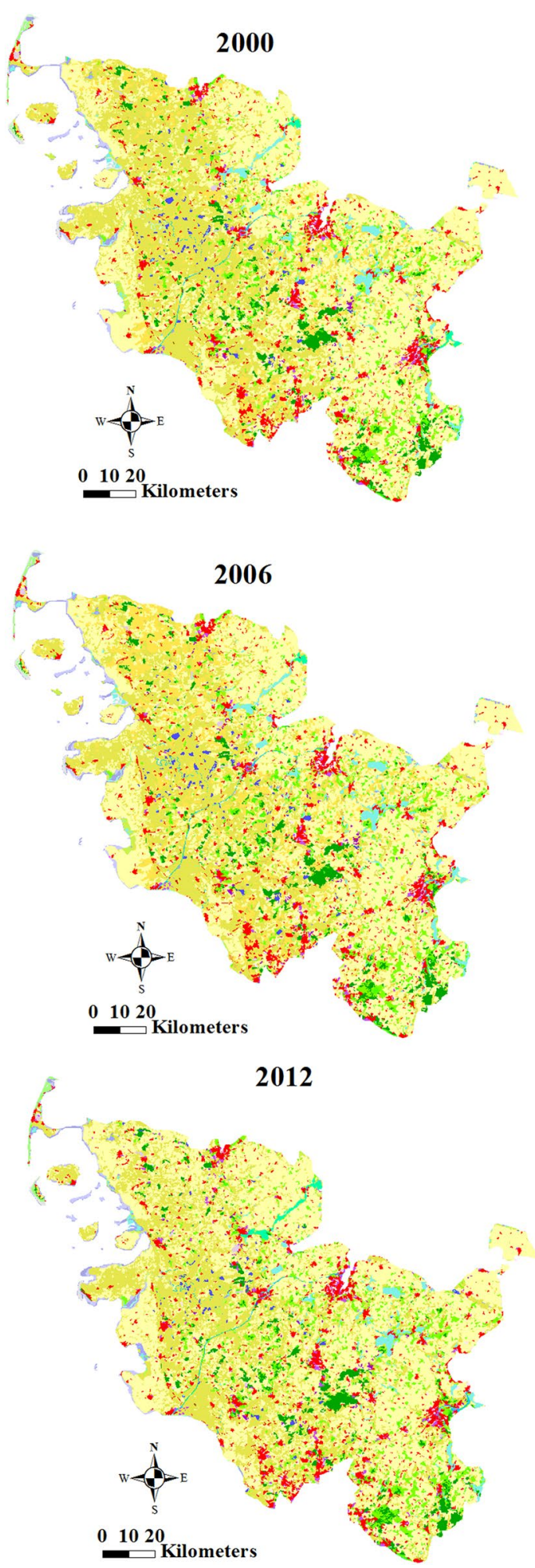

CORINE Land Cover Classes

Continuous urban fabric

Discontinuous urban fabric

Industrial or commercial units

Road and rail networks and associated land

Port areas

Airports

Mineral extraction sites

Dump sites

Construction sites

Green urban areas

Sport and leisure facilities

Non-irrigated arable land

Fruit trees and berry plantations

Pastures

Complex cultivation patterns

Land principally occupied by agriculture

Broad-leaved forest

Coniferous forest

Mixed forest

Natural grasslands

Moors and heathland

Transitional woodland-shrub

Beaches, dunes, sands

Sparsely vegetated areas

Inland marshes

Peat bogs

Salt marshes

Intertidal flats

Water courses

Water bodies

Coastal lagoons

Estuaries

Fig. 2 CORINE land cover maps of Schleswig-Holstein in 2000 (a), 2006 (b) and 2012 (c) 
The same methods were used to map, calculate and analyze the annual total NPP and the annual total stored NPP.

Ratio between NPP and GPP and calculated vegetative respiration The annual total GPP and the annual total NPP maps were produced based on the CORINE land cover classes for calculating the ratio between the NPP and GPP of each land cover class.

The vegetation respiration was derived from the difference between the annual total GPP and the annual total NPP based on the definition of the vegetation respiration $[22,31]$. The vegetation respiration based on the CORINE land cover classes was evaluated by deducting the annual total NPP from the annual total GPP in ArcGIS 10.3.

Hotspots and cold spots of annual total GPP and annual total NPP Hotspots are statistically significant spatial clusters of high values, and cold spots are spatial clusters of low values [46]. They were used here to identify the locations of significant hotspots and cold spots of the annual total GPP and the annual total NPP in 2000, 2006 and 2012. The data were derived from the raster data sets of MODIS annual total GPP and MODIS annual total NPP. The raster patches were converted into polygons with the raster to polygon tool in ArcGIS 10.3. Afterwards, the hot spot analysis (Getis-Ord Gi*) tool was used to identify the hotspots and cold spots of the annual total GPP and the annual total NPP. The p-values, classified with typical probabilities of $0.01,0.05$ and 0.1 measure, and the Z-scores, with $90 \%$ (b<- 1.65 or $>+1.65)$, $95 \%$ $(\mathrm{b}<-1.96$ or $>+1.96)$ and $99 \%(\mathrm{~b}<-2.58$ or $>+2.58)$ confidence levels, were simply standard deviations [47]. The p-values and Z-scores indicated whether spatially clustered areas with either high or low values were more pronounced than one would expect in a random distribution of those same values.

\section{Results}

\section{Land cover distributions in 2000, 2006 and 2012}

The area of the different land cover and their percentages are shown in Table 1. Differences appeared in the absolute area and their relative share (percentage) in the 3 years. "Non-irrigated arable land", "pastures" and "complex cultivation patterns" were clearly dominant land cover classes in 2000 and 2006. "Non-irrigated arable land", "pastures" and "discontinuous urban fabric" dominated larger area than the other land cover classes in 2012, according the CORINE land cover maps. The area of "non-irrigated arable land" decreased from 666,449 ha in 2000 to 666,186 ha in 2006 and then increased to
746,016 ha in 2012. During the same period, the area of "pastures" changed from 452,238 to 367,189 ha and then to 441,388 ha from 2000 until 2006 and then to 2012 . The percentage of the different land cover types had similar trends as the land cover area. The percentages of the area in "non-irrigated arable land" and in "pastures" decreased from 1990 to 2006, and then increased from 2006 to 2012. "Fruit trees and berry plantations", "road and rail networks and associated land" and "construction sites" covered the smallest area in Schleswig-Holstein in 2000 and 2006. So did "sparsely vegetated areas", "construction sites" and "fruit trees and berry plantations" in 2012. "Non-irrigated arable land" and "pastures" were the dominating land cover classes for the years 2000, 2006 sparsely vegetated 1 year to the other.

\section{GPP distributions in Schleswig-Holstein in 2000, 2006 and 2012}

The annual total GPP of Schleswig-Holstein for the years 2000, 2006 and 2012 is presented in six classes in Fig. 3. The annual total GPP was the highest in 2000 and the lowest in 2006 among the 3 years, fluctuating in different regions in 2000, 2006 and 2012. The pixels with high annual total GPP were mainly in "pastures" and "coniferous forest". The low annual total GPP appeared in "beaches, dunes and sands" and "intertidal flats".

\section{GPP distribution based on land cover classes}

The annual total GPP presents the carbon stored with a certain spatial and temporal unit $\left(\mathrm{g} \mathrm{C} \mathrm{m}^{-2}\right.$ year $\left.^{-1}\right)$, while the annual total stored GPP shows the carbon stored with a certain temporal unit $\left(\mathrm{Mg} \mathrm{C}\right.$ year $\left.^{-1}\right)$, reflecting in the spatial distribution. The annual total GPP and the annual total stored GPP in Schleswig-Holstein for the years 2000, 2006 and 2012 are shown in Figs. 4 and 5. The land cover class that had the largest annual total GPP was "coniferous forest" in 2000, followed by "pastures", "peat bogs', "mixed forest" and "broad-leaved forest". The land cover classes that had the largest annual total GPP in 2006 were the same as the land cover classes in 2000 . However, the value of the annual total GPP of the land cover classes in 2006 was less than the value of the annual total GPP in 2000. "Coniferous forest", "mixed forest", "pastures", "broad-leaved forest" and "complex cultivation patterns" constituted the land cover classes with the largest annual total GPP in 2012.

The annual total stored GPP in 2000 was higher than those in 2006 and 2012. "Non-irrigated arable land", "pastures", "complex cultivation patterns", and "broad-leaved forest" had the highest annual total GPP among the 17 land cover classes in 2000 and 2006. "Coniferous forest" replaced "complex cultivation patterns" as one of the top four land cover classes containing large amount of the 
Table 1 Area and the percentage of land cover classes of Schleswig-Holstein in 2000, 2006 and 2012

\begin{tabular}{|c|c|c|c|c|c|c|c|}
\hline \multirow{2}{*}{$\begin{array}{l}\text { Land cover classes } \\
\text { (CORINE Level 1) }\end{array}$} & \multirow{2}{*}{$\begin{array}{l}\text { Land cover classes } \\
\text { (CORINE Level 3) }\end{array}$} & \multicolumn{2}{|l|}{2000} & \multicolumn{2}{|l|}{2006} & \multicolumn{2}{|l|}{2012} \\
\hline & & Area (ha) & Percentage (\%) & Area (ha) & Percentage (\%) & Area (ha) & Percentage (\%) \\
\hline \multirow[t]{11}{*}{ Artificial surfaces } & Continuous urban fabric & 997 & 0.06 & 1030 & 0.07 & 527 & 0.03 \\
\hline & Discontinuous urban fabric & 84,572 & 5.40 & 88,601 & 5.66 & 100,177 & 6.40 \\
\hline & $\begin{array}{l}\text { Industrial or commercial } \\
\text { units }\end{array}$ & 7487 & 0.48 & 9076 & 0.58 & 14,877 & 0.95 \\
\hline & $\begin{array}{l}\text { Road and rail networks and } \\
\text { associated land }\end{array}$ & 338 & 0.02 & 486 & 0.03 & 472 & 0.03 \\
\hline & Port areas & 926 & 0.06 & 965 & 0.06 & 489 & 0.03 \\
\hline & Airports & 2446 & 0.16 & 2438 & 0.16 & 2465 & 0.16 \\
\hline & Mineral extraction sites & 2814 & 0.18 & 3504 & 0.22 & 2987 & 0.19 \\
\hline & Dump sites & 719 & 0.05 & 807 & 0.05 & 380 & 0.02 \\
\hline & Construction sites & 493 & 0.03 & 308 & 0.02 & 56 & 0.00 \\
\hline & Green urban areas & 1148 & 0.07 & 1148 & 0.07 & 2063 & 0.13 \\
\hline & Sport and leisure facilities & 5827 & 0.37 & 7100 & 0.45 & 9708 & 0.62 \\
\hline \multirow[t]{5}{*}{ Agricultural areas } & Non-irrigated arable land & 666,449 & 42.59 & 666,186 & 42.57 & 746,015 & 47.67 \\
\hline & $\begin{array}{l}\text { Fruit trees and berry planta- } \\
\text { tions }\end{array}$ & 259 & 0.02 & 293 & 0.02 & 244 & 0.02 \\
\hline & Pastures & 452,238 & 28.90 & 367,189 & 23.46 & 441,388 & 28.21 \\
\hline & Complex cultivation patterns & 93,850 & 6.00 & 164,279 & 10.50 & 743 & 0.05 \\
\hline & $\begin{array}{l}\text { Land principally occupied by } \\
\text { agriculture }\end{array}$ & 24,262 & 1.55 & 27,661 & 1.77 & 6488 & 0.41 \\
\hline \multirow{8}{*}{$\begin{array}{l}\text { Forest and semi-natural } \\
\text { areas }\end{array}$} & Broad-leaved forest & 60,288 & 3.85 & 62,450 & 3.99 & 81,247 & 5.19 \\
\hline & Coniferous forest & 51,808 & 3.31 & 51,759 & 3.31 & 53,196 & 3.40 \\
\hline & Mixed forest & 22,005 & 1.41 & 22,863 & 1.46 & 14,302 & 0.91 \\
\hline & Natural grasslands & 9400 & 0.60 & 9129 & 0.58 & 9519 & 0.61 \\
\hline & Moors and heathland & 3056 & 0.20 & 3015 & 0.19 & 4477 & 0.29 \\
\hline & Transitional woodland-shrub & 2132 & 0.14 & 2206 & 0.14 & 3934 & 0.25 \\
\hline & Beaches, dunes, sands & 4653 & 0.30 & 4433 & 0.28 & 2032 & 0.13 \\
\hline & Sparsely vegetated areas & 1321 & 0.08 & 1321 & 0.08 & 29 & 0.00 \\
\hline \multirow[t]{4}{*}{ Wetlands } & Inland marshes & 4307 & 0.28 & 4480 & 0.29 & 4729 & 0.30 \\
\hline & Peat bogs & 8946 & 0.57 & 9484 & 0.61 & 6623 & 0.42 \\
\hline & Salt marshes & 8476 & 0.54 & 8735 & 0.56 & 11,755 & 0.75 \\
\hline & Intertidal flats & 7977 & 0.51 & 8130 & 0.52 & 7485 & 0.48 \\
\hline \multirow[t]{4}{*}{ Water bodies } & Water courses & 3241 & 0.21 & 3606 & 0.23 & 4308 & 0.28 \\
\hline & Water bodies & 27,950 & 1.79 & 29,781 & 1.90 & 25,556 & 1.63 \\
\hline & Coastal lagoons & 2817 & 0.18 & 1117 & 0.07 & 5340 & 0.34 \\
\hline & Estuaries & 1716 & 0.11 & 1344 & 0.09 & 1313 & 0.08 \\
\hline
\end{tabular}

annual total stored GPP in 2012. The annual total GPP and the annual total stored GPP were distinct from one land cover class to another, and either the annual total GPP or the annual total stored GPP in different years was various.

\section{Correlations among annual total GPP, land cover area and annual total stored GPP}

Correlation analysis among the annual total stored GPP, the annual total GPP and the land cover area showed that the annual total stored GPP was significantly affected by the other two factors. The strong effect of the land cover area indicated that the land cover area had the most important influence on the annual total stored GPP, and land cover had a considerably strong influence on the annual total GPP (Table 2).

\section{NPP of Schleswig-Holstein in 2000, 2006 and 2012}

The annual total NPP represents the NPP stored in biomass with a special unit in 1 year, and the annual total stored NPP is the amount of NPP in one land cover class. Figure 6 presents the annual total NPP maps of Schleswig-Holstein in 2000, 2006 and 2012. The annual 
Table 2 Spearman correlations among annual total GPP $\left(\mathrm{g} \mathrm{C} \mathrm{m}^{-2}\right.$ year $\left.^{-1}\right)$, land cover area (ha) and annual total stored GPP based on land cover classes ( $\mathrm{Mg} \mathrm{C}$ year $^{-1}$ )

\begin{tabular}{llll}
\hline & GPP & Land cover area & $\begin{array}{l}\text { Stored GPP } \\
\text { based on land } \\
\text { cover }\end{array}$ \\
\hline GPP & 1.00 & $0.24^{*}$ & $0.26^{*}$ \\
Land cover area & 1.00 & $1.00^{* *}$ \\
$\begin{array}{l}\text { Stored GPP based } \\
\text { on land cover }\end{array}$ & 1.00 \\
${ }^{*}$ Correlation is significant at the 0.05 level \\
${ }^{* *}$ Correlation is significant at the 0.01 level
\end{tabular}

total NPP in 2000 was larger than that in 2012 and 2006, and was the lowest in 2006 .

\section{NPP distributions based on land cover classes}

The carbon stored in vegetation with a certain spatial and temporal unit is denoted by the annual total NPP. Figures 7 and 8 present the annual total NPP and the annual total stored NPP based on land cover classes for the years 2000, 2006 and 2012. "Pastures", "mixed forest", "transitional woodland-shrub" and "peat bogs" had the largest annual total NPP in 2000. "Pastures", "complex cultivation patterns", "transitional woodland-shrub", "peat bogs" and "fruit trees and berry plantations" and "coniferous forest" produced the highest annual total NPP in 2006. "Coniferous forest", "complex cultivation patterns", "mixed forest", "pastures" and "natural grasslands" had the largest annual total NPP in 2012.

The annual total stored NPP had the highest and the lowest values in 2000 and 2006, respectively. "Non-irrigated arable land", "pastures", "complex cultivation patterns", and "broad-leaved forest" had the highest annual total NPP among the land cover types for the years 2000 and 2006. "Coniferous forest" took the position of "complex cultivation patterns" as one of the top four land cover classes that contained large amount of the annual stored NPP in 2012.

\section{Correlations among annual total NPP, land cover area and annual total stored NPP}

The annual total NPP and the land cover area, which might influence the annual total stored NPP were analyzed using correlation analysis. Table 3 presents that the annual total NPP and the land cover area significantly affected the annual total stored NPP. The land cover area had the most important effect on the annual total stored NPP as indicated by the very high coefficient value.

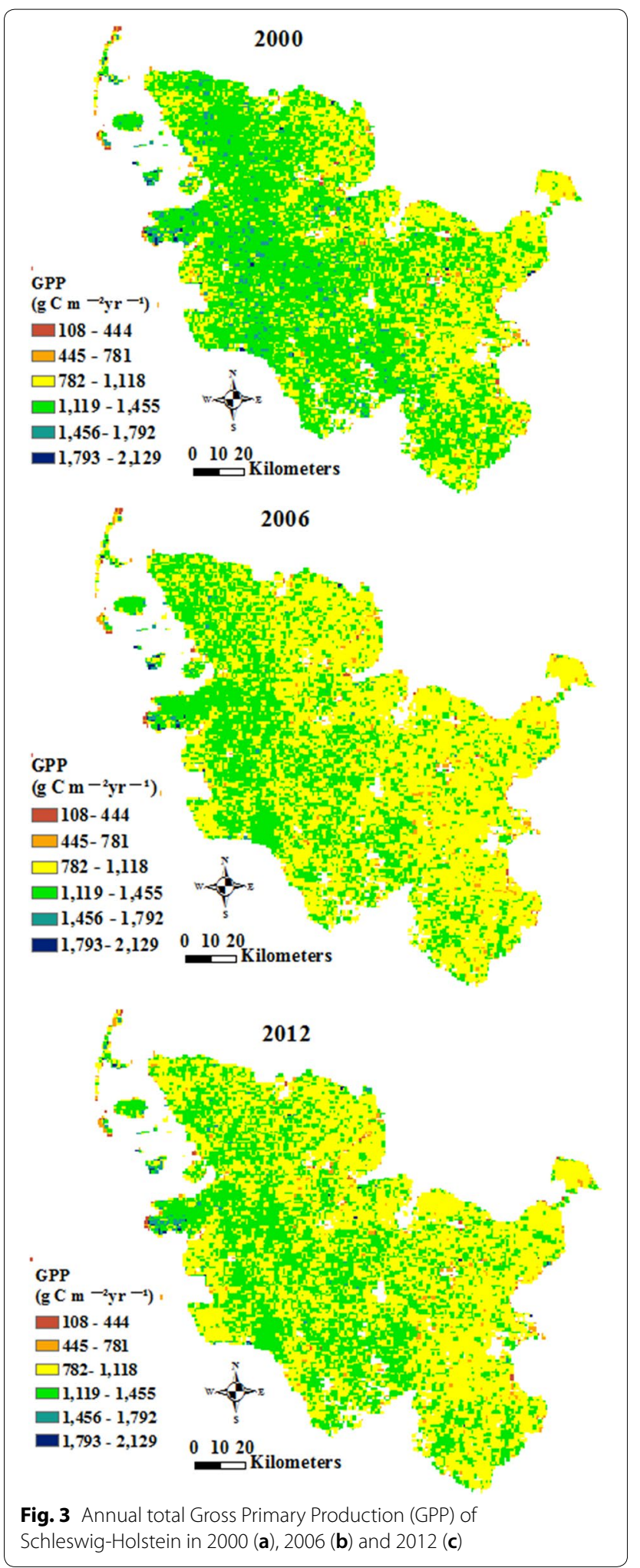




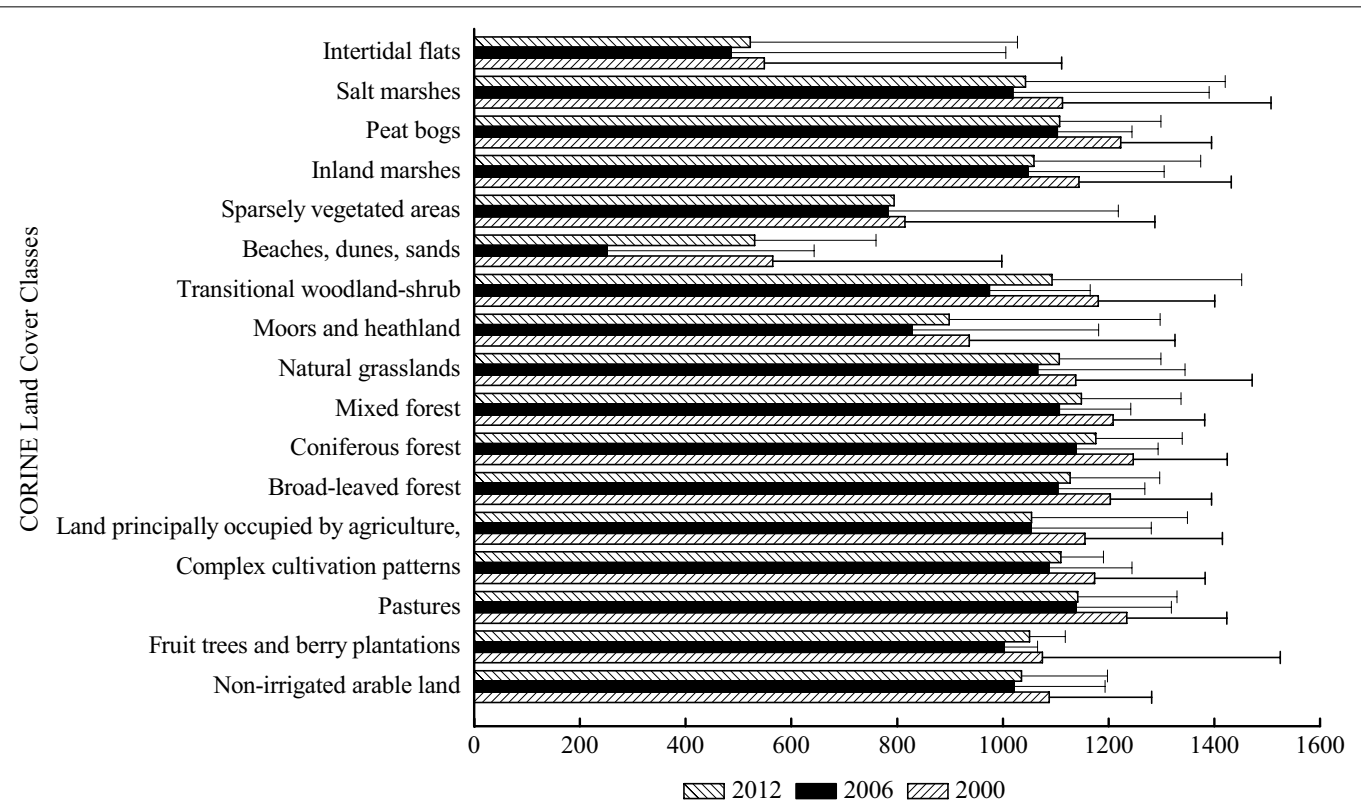

Fig. 4 Annual total GPP ( $\mathrm{g} \mathrm{m}^{-2}$ year $^{-1}$ ) based on land cover classes of Schleswig-Holstein in 2000, 2006 and 2012

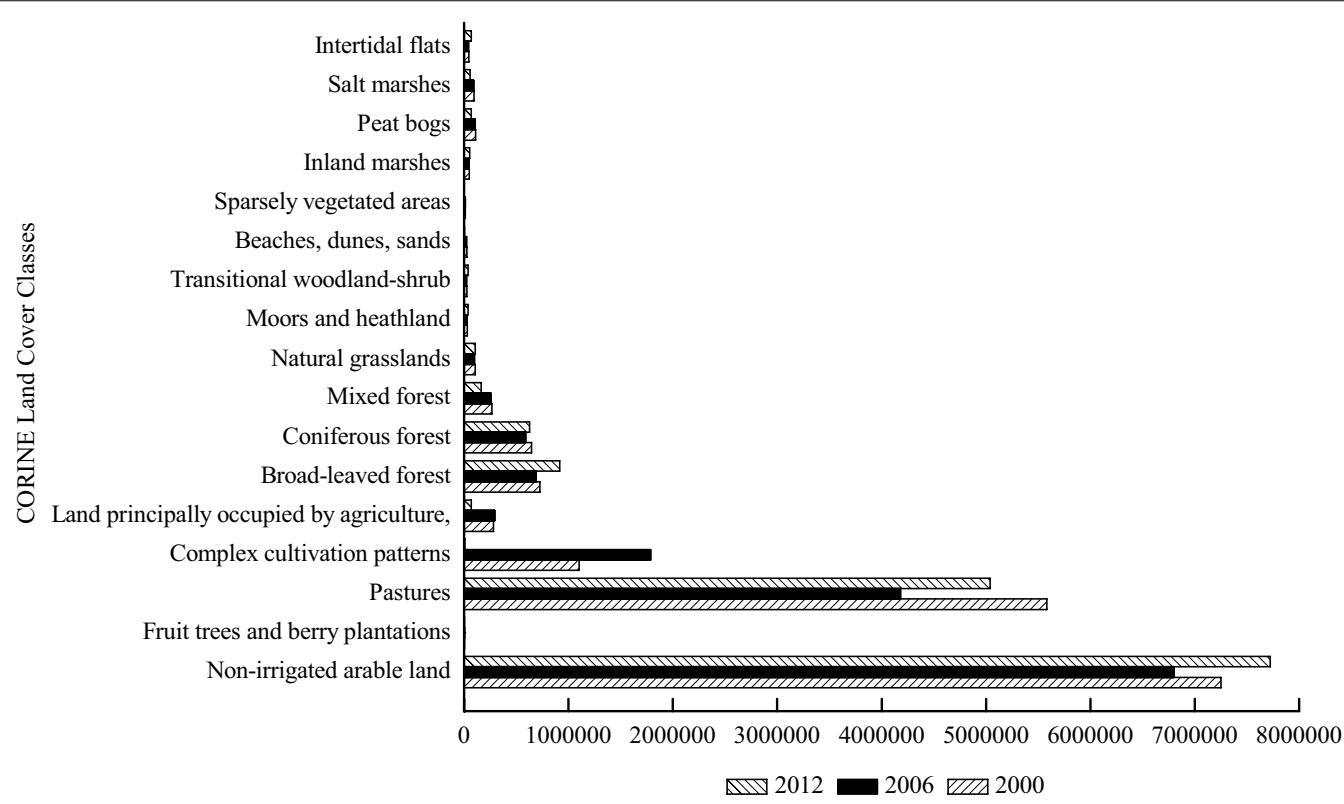

Fig. 5 Annual total stored GPP (Mg C year ${ }^{-1}$ ) based on land cover classes of Schleswig-Holstein in 2000, 2006 and 2012

\section{Annual total NPP/GPP, and calculated respiration based on land cover classes}

The calculated respiration by green plants per unit of time and space was estimated as the difference between the annual total GPP and NPP. The respiration maps based on CORINE land cover classes in SchleswigHolstein for the years 2000, 2006 and 2012 are shown in Fig. 9 and Table 4. The respiration in 2006 was the highest, and 2012 had the lowest respiration among the 3 years. The lowest calculated respiration appeared in "intertidal flats" and "beaches, dunes, sands", shown in red in Fig. 9. In contrast, the ratio between respiration and GPP in 2006 was lower than those in 2000 and 2012. These ratios in the land cover class of "intertidal 

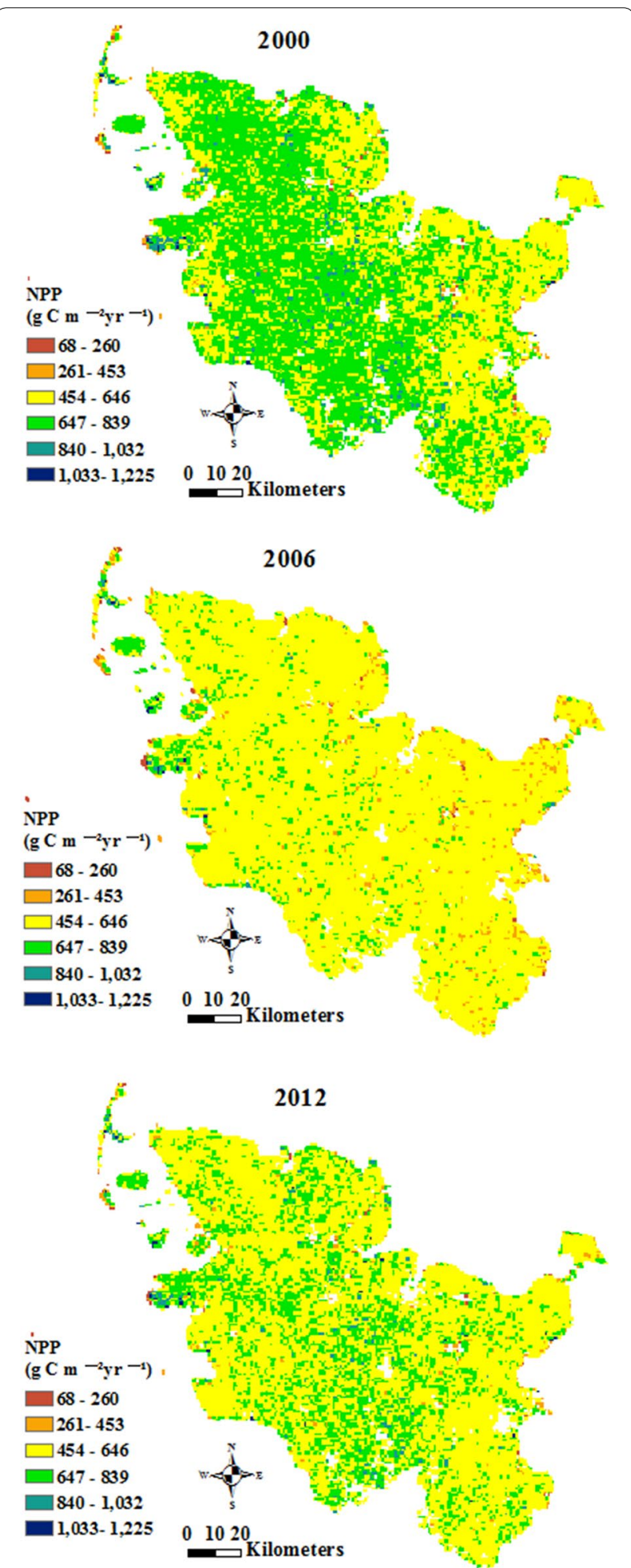

Fig. 6 Annual total Net Primary Production (NPP) of Schleswig-Holstein in 2000 (a), 2006 (b) and 2012 (c) flats" were $33.25 \%, 36.09 \%$ and $32.52 \%$ for the years 2000 , 2006 and 2012, respectively. "Intertidal flats" had the lowest ratio between respiration and GPP. "Beaches, dunes, sands" (48.50\% in 2000 and $49.23 \%$ in 2006) and "sparsely vegetated areas" $(50.62 \%)$ had the greatest ratios for the years 2000, 2006 and 2012. These results indicated that more energy was been fixed by autotrophs in "intertidal flats" than in "beaches, dunes, sands", "broad-leaved forest" or "sparsely vegetated areas".

The annual total NPP/GPP based on the land cover classes for the years 2000, 2006 and 2012 showed fluctuations (Fig. 10 and Table 4). The average ratios of the annual total NPP/GPP were $0.5647,0.5350$ and 0.5573 in 2000, 2006 and 2012, respectively. The range between the minimum and the maximum of the annual total NPP/ GPP in 2006 was larger than that in 2000 but smaller than that in 2012. The annual total NPP/GPP was different from one land cover class to another in SchleswigHolstein for the years 2000, 2006 and 2012. "Intertidal flats" had the maximum annual total NPP/GPP (0.6675 in 2000, 0.6391 in 2006 and 0.6747 in 2012). "Beaches, dunes, sands" (in 2000 and 2006) and "sparsely vegetated areas" (in 2012) were the land cover classes with the minimum ratios, shown in red in Fig. 10. The land cover classes with the minimum and maximum values of the annual total NPP/GPP were the same as the land cover classes those had the highest and lowest ratios between respiration and GPP.

\section{Identifying hotspots and cold spots for annual total GPP and annual total NPP of Schleswig-Holstein}

Estimating the spatial distributions of the hotspots and cold spots for the annual total GPP and NPP presents core distribution areas. The spatial distributions of the hotspots and cold spots for the annual total GPP and the annual total NPP in Schleswig-Holstein for the years 2000, 2006 and 2012 show core distribution areas (Fig. 11). The hotspot areas were in the central-western to the central-southern areas of Schleswig-Holstein in 2000, 2006 and 2012, forming an adjacent significant hotspot area with high annual total GPP. The cold spotareas primarily occupied the edges of the western and eastern parts of the federal state. The areas of the hotspots and the cold spots fluctuated during the 3 years (Table 5). Approximately $36.12 \%, 32.69 \%$ and $32.38 \%$ of the state' areas were distributed in the identified hotspot areas for the years 2000, 2006 and 2012, respectively. Meanwhile, the cold spots accounted for $33.72 \%, 33.84 \%$ and $30.73 \%$ of the total areas of the state in the 3 years, respectively. The percentage of non-significant areas increased from 


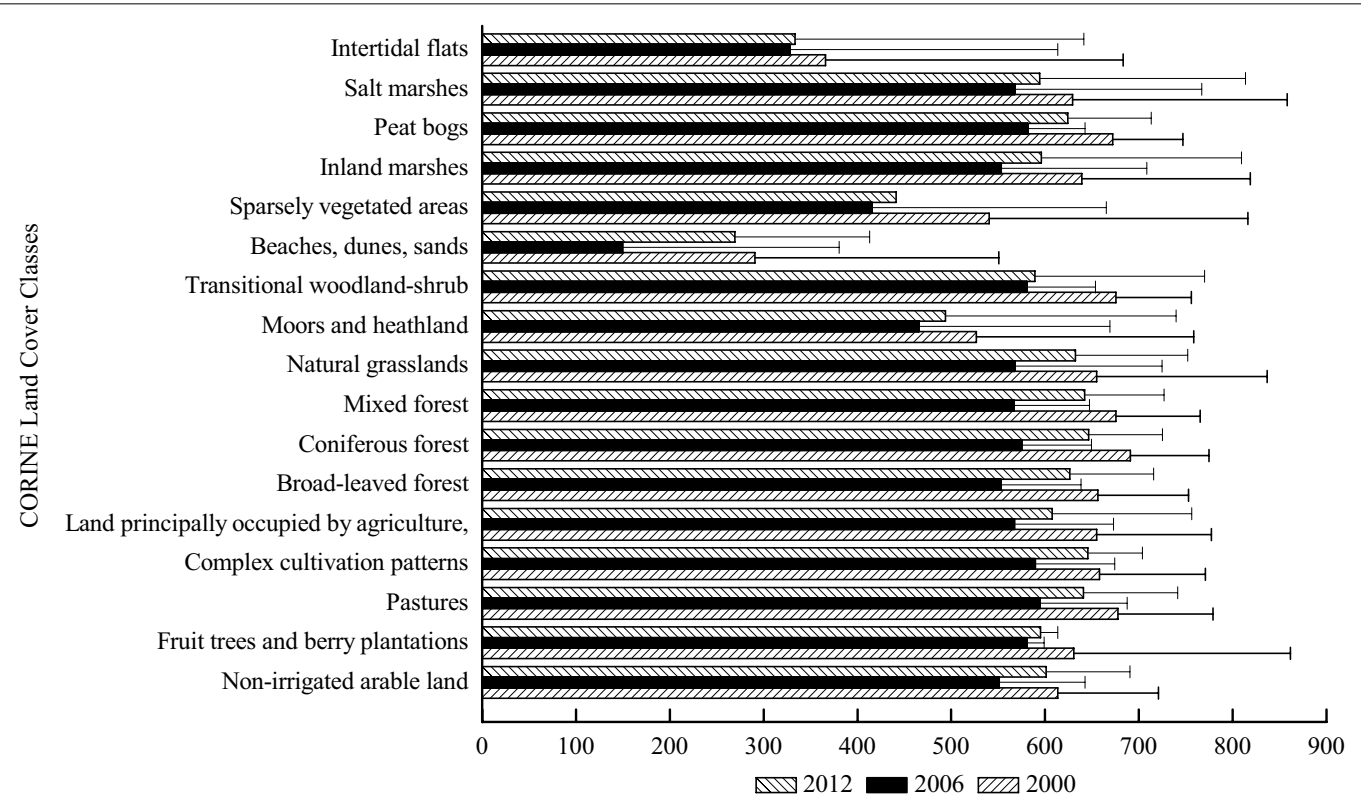

Fig. 7 Annual total NPP ( $\mathrm{g} \mathrm{m}^{-2}$ year $^{-1}$ ) based on land cover classes of Schleswig-Holstein in 2000, 2006 and 2012

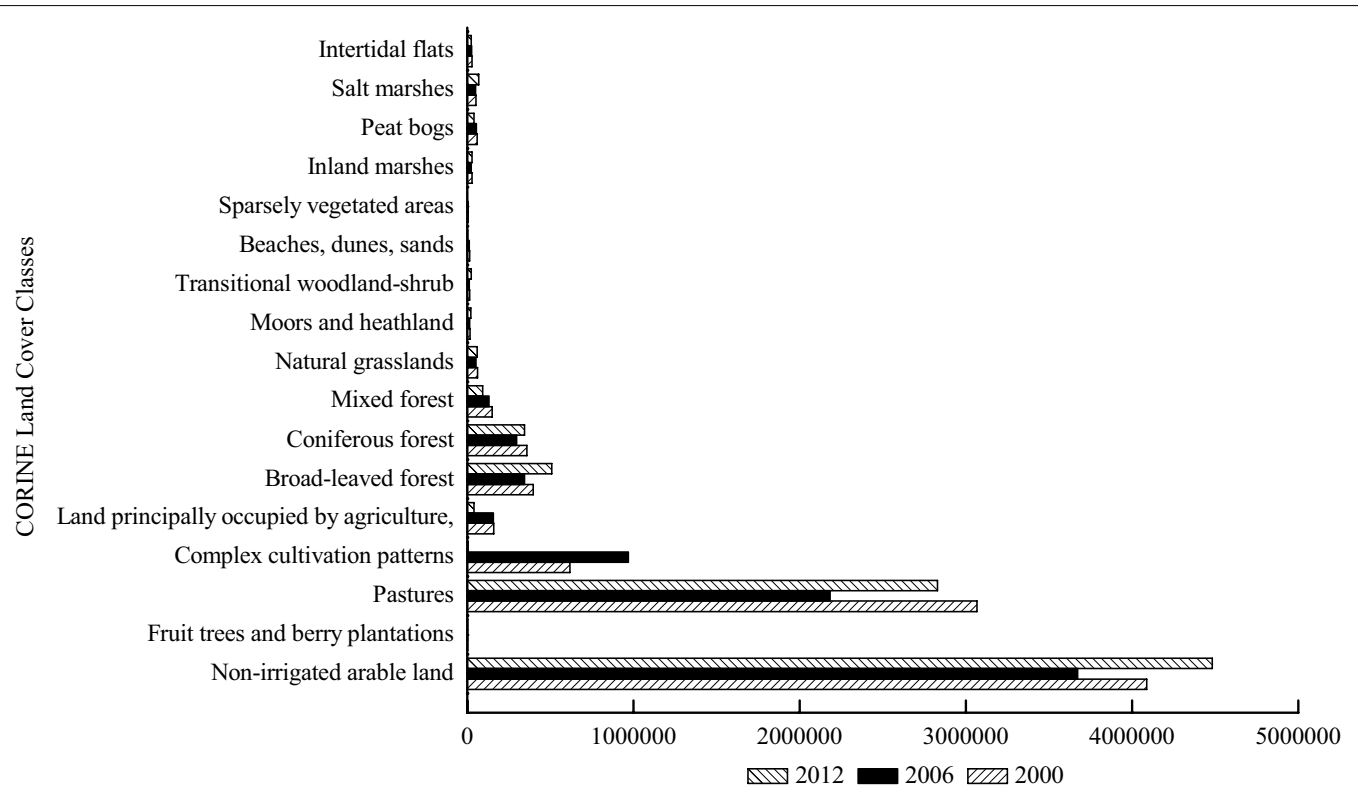

Fig. 8 Annual total stored NPP (Mg C year ${ }^{-1}$ ) based on land cover classes of Schleswig-Holstein in 2000, 2006 and 2012

$30.16 \%$ in 2000 to $33.47 \%$ in 2006 and then reached $36.89 \%$ in 2012 . The decrease of hotspots areas and extension of the areas of non-significant results indicated a fluctuation in the cold spot areas during the study periods. The distributions of the hotspots and the cold spot areas of the annual total NPP showed similar trends as the distribution of the annual total GPP, covering areas from the central-western to the central-southern areas of the state in 2000, 2006 and 2012. Furthermore, the distribution of hotspot areas in 2012 were much more fragmented than the distributions in 2000 and in 2006, besides that the areas occupied by the hotspots of the annual total NPP declined during the study period. Contrarily, the growth of the non-significant areas proceeded rapidly, increasing from $28.93 \%$ of the total area of the state in 2000 to $44.94 \%$ in 2012 . The percentage of the 
cold spot areas (around 31.10\%) was similar in 2000 and 2006, and then decreased to $24.73 \%$ in 2012 . However, the decline in the areas of the hotspot and cold spot areas was much more significant for the annual total NPP than the decrease of the areas of the annual total GPP.

\section{Discussion}

The CORINE land cover maps have been widely used for assessing ecological factors and stability at the European, national, regional and local scales [14, 48-50], or for evaluating ecosystem services [32, 51]. The CORINE land cover maps of Germany were mapped with a specific national approach, using ATKIS [52]. Therefore, CORINE land cover maps are well adapted for studies for broader extents and resolutions. The findings in this study showed that "non-irrigated arable land" and "pastures" were the land cover classes that occupied the largest amount of area in Schleswig-Holstein for the years 2000, 2006 and 2012 (Table 1). The outcomes agree with results about land cover and land use distributions in the Bornhöved Lakes, Northern Germany, estimated with multiple data sources [53]. This distribution trend resulted from the significant dominance of agricultural areas in Schleswig-Holstein due to social-economic planning by the federal government [54]. The wide distributions of "non-irrigated arable land" and "pastures" were strengthened by the European Commission Policies, for instance by the Common Agricultural Policy (CAP) [26]. These results are in agreement with Rounsevell et al. [55], who found that over $50 \%$ of the surface area of the European Union was covered by agriculture.

Land cover distributions are driven by complex environmental, social and economic conditions that are focal points for sustainable land cover plans [56, 57]. The distributions frequently change due to human activities that have been increasingly influenced by political plans during the last few centuries, for instance urbanization or intensively using agricultural land $[37,58]$. Land cover classes in Schleswig-Holstein are often initiated by the cultivation of silage maize for biogas plants that have been a widely discussed political issue in Germany. As a renewable energy source (RES) system in Germany, the system was established in 1980 and became a consensual aim in 2010 because of the continuously growing number of beneficiaries [59]. An enormous number of biogasplants grown monoculture for electricity production were produced from the 1980s to 2000s, enhancing the annual GPP and NPP stocks. However, the wide production of biogas plants induces to erosion, eutrophication, soil carbon loss and monotonous landscape [60]. Take cultivating silage maize for example, it may be an important factor which provides the highest overall impacts on land cover and land cover changes since the 1980s because of the policy [61]. Following the transitional energy regime, the number of biogas plants in Germany significantly grew 57.6 times from 1992 until 2013 [62]. As the critically cultivated area of biogas plants, pastures and maize has expended rapidly in recent decades [63, 64]. SchleswigHolstein has widely covered by "pastures", "non-irrigated arable land" or "complex cultivation patterns", because of a prime step for developing RES.

The land cover classes in Schleswig-Holstein which had the largest annual total GPP and NPP (Figs. 4 and 7) were "coniferous forest", "mixed forest", "broadleaved forest", and "pastures". The annual total NPP in this study had similar results as previous studies about NPP (456.8 $\mathrm{g} \mathrm{C} \mathrm{m}^{-2}$ year $^{-1}$ NPP in needle-leaf forest, $613.1 \mathrm{~g} \mathrm{C} \mathrm{m}^{-2}$ year $^{-1}$ NPP in broad-leaf forest, $559.5 \mathrm{~g}$ $\mathrm{C} \mathrm{m}^{-2}$ year $^{-1} \mathrm{~g} \mathrm{C} \mathrm{m}^{-2}$ year $^{-1} \mathrm{NPP}$ in mixed forest and 122.6 in grass $\mathrm{g} \mathrm{C} \mathrm{m}^{-2}$ year $^{-1} \mathrm{NPP}$ in grass land) in Chinese terrestrial ecosystems, representing that the annual total NPP in forests was higher than in grassland $[22,26]$. The values of the annual total NPP in the three types of Chinese forests and one grassland were lower than the annual total NPP of the three land cover types in Schleswig-Holstein because the geophysical and geochemical conditions in China were much more heterogeneous than those in Schleswig-Holsten. The heterogeneous conditions may lead to negative influences on the annual total GPP and NPP through affecting vegetation growth [65]. In addition to the distinctions of the annual total GPP and NPP owing to the locaton of the study area, nutrients availability which were imported during the process of fertilization, led to "pastures" showing a similar performance trend as forest (Table 1) [6,58]. However, the annual total GPP and the annual total NPP in the other land cover classes were different from the annual total GPP and the annual total NPP in pastures and forests. The reasons for the differences among the 17 land cover classes are that the land cover changes may have impacts on albedo, evapotranspiration, and sources and sinks of gases which are the ingredients for biological carbon sequestration [66].

The annual total stored GPP and the annual total stored NPP (Figs. 6 and 9) in "non-irrigated arable land" and "pastures" were much higher than those in the other land cover classes although the annual total GPP and the annual total NPP in "non-irrigated arable land" and "pastures" were close to those in the other land cover classes. The distinctions of the annual total stored GPP and the annual total stored NPP among the various land cover classes illustrate that the influences from the annual total GPP and the annual total NPP on the annual total stored GPP and the annual total stored NPP were not 

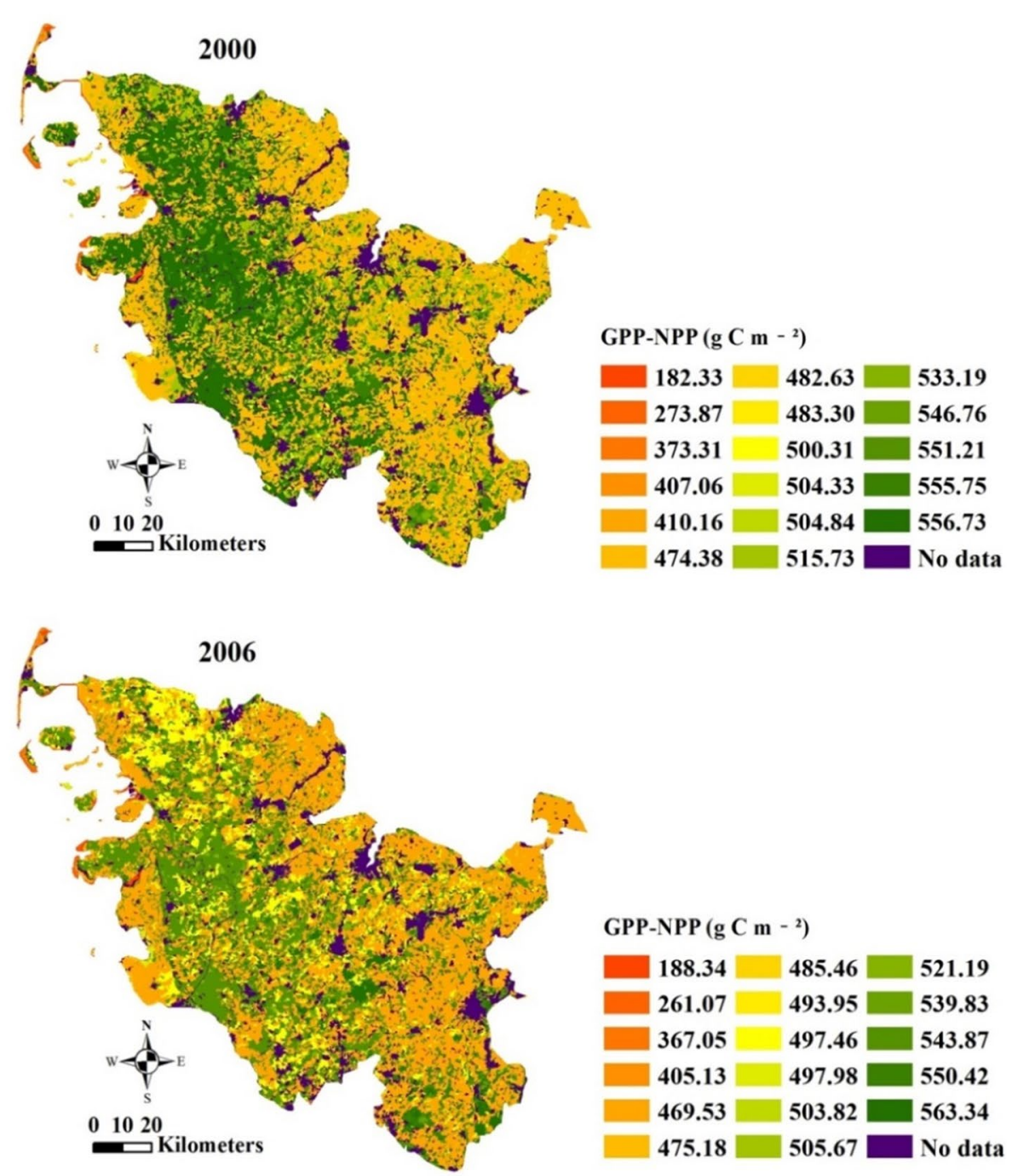

GPP-NPP ( $\left.\mathrm{g} \mathrm{C} \mathrm{m}^{-2}\right)$

\begin{tabular}{|l|l|l|l|}
\hline 188.34 & 485.46 & 521.19 \\
\hline 261.07 & 493.95 & 539.83 \\
\hline 367.05 & 497.46 & 543.87 \\
\hline 405.13 & 497.98 & 550.42 \\
\hline 469.53 & 503.82 & 563.34 \\
\hline 475.18 & 505.67 & No data \\
\hline
\end{tabular}
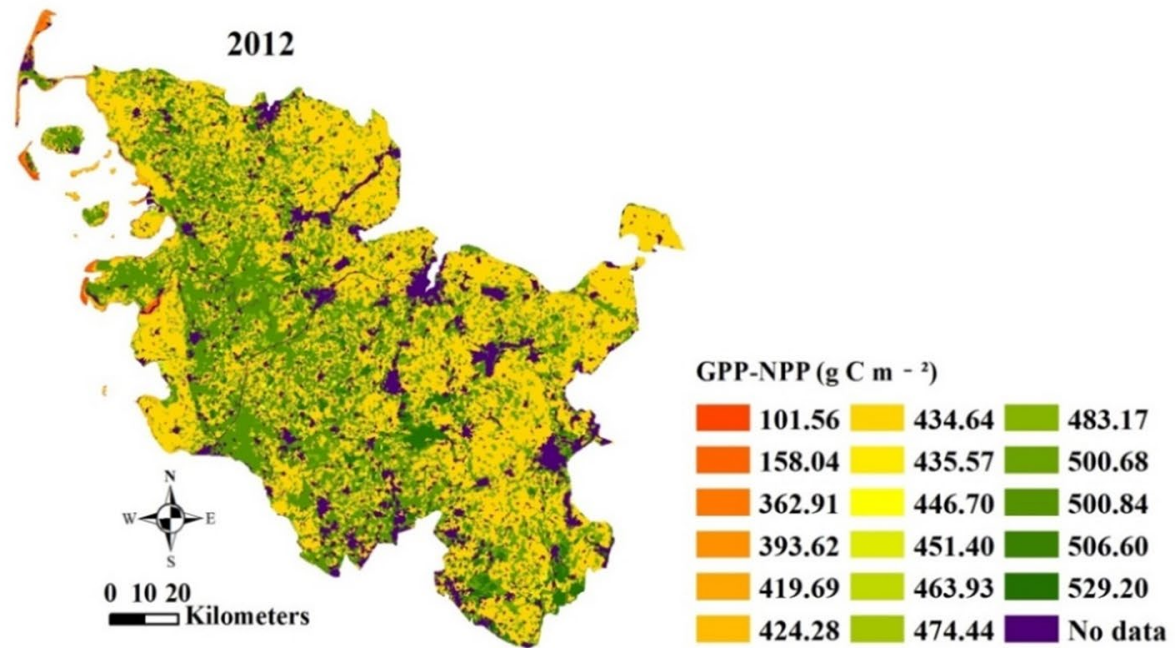

Fig. 9 Maps of calculated respiration based on land cover classes of Schleswig-Holstein in 2000 (a), 2006 (b) and 2012 (c) 
Table 3 Correlations among annual total NPP $\left(\mathrm{g} \mathrm{C}^{-2}\right.$ year $\left.^{-1}\right)$, land cover area (ha) and annual total stored NPP spearman correlations based on land cover classes ( $\mathrm{MgC}_{\text {year }}{ }^{-1}$ )

\begin{tabular}{llll}
\hline & NPP & $\begin{array}{l}\text { Land cover } \\
\text { area }\end{array}$ & $\begin{array}{l}\text { Stored NPP based } \\
\text { on land cover }\end{array}$ \\
\hline NPP & 1.00 & $0.24^{*}$ & $0.25^{*}$ \\
Land cover area & & 1.00 & $1.00^{* *}$ \\
$\begin{array}{l}\text { Stored NPP based on } \\
\text { land cover }\end{array}$ & & 1.00 \\
\hline
\end{tabular}

* Correlation is significant at the 0.05 level

* Correlation is significant at the 0.01 level

as significant as the influences from the land cover area (Tables 2 and 3). These results suggest that the land cover distributions and changes significantly influence biological sequestration $[23,67,68]$, such as GPP and NPP. The higher of the annual total stored GPP and the annual total stored NPP values imply more carbon fixation and lower $\mathrm{CO}_{2}$ emissions. Hence, the land cover managers of Schleswig-Holstein can increase greenhouse gas fixation (e.g. $\mathrm{CO}_{2}$ ) through afforestation and sustainable intensification of agriculture, which would lead to increases in areas of "broad-leaved forest", "coniferous forest", "mixed forest", "pastures" and "non-irrigated arable land". However, this will be a long-term process due to making agreements of property rights on land cover and land use changes by landholders and governmental managers in Germany [69]. Therefore, providing payments to landholders whose land cover and land use area would be decreased, and increasing the areas of "broad-leaved forest", "coniferous forest", "mixed forest", "pastures" and "non-irrigated arable land", might be good options [70, $71]$.

The annual respiration from plants was calculated as the difference between GPP and NPP [20] (Fig. 10). The calculated respiration on the land cover classes of Schleswig-Holstein ranged from approximately $182.33 \mathrm{~g}$ $\mathrm{C} \mathrm{m}^{-2}$ year $^{-1}$ to $556.73 \mathrm{~g} \mathrm{C} \mathrm{m}^{-2}$ year $^{-1}$ in 2000 , from 188.34 to $563.34 \mathrm{~g} \mathrm{C} \mathrm{m}^{-2}$ year $^{-1}$ in 2006 , and from 101.56 to $529.20 \mathrm{~g} \mathrm{C} \mathrm{m}^{-2}$ year $^{-1}$ in 2012 . However, the calculated respiration and GPP for different ages of forests ranged from 230 to $340 \mathrm{~g} \mathrm{C} \mathrm{m}^{-2}$ year $^{-1}[15,19]$. The large differences in these calculated respiration values resulted from the multiple land cover classes in the study and the single land cover class (forest) in the study of Goulden et al. [19].

The NPP/GPP ratios, which are critical for understanding the carbon stocks of ecosystems and their responses to climate change [64, 72], were between 0.5011 and 0.6774 in Schleswig-Holstein. A study on NPP/GPP ratios at the global scale found that the ratio fluctuated around an average of 0.5 , and the ratio stabilized at approximately 0.61 between $30^{\circ}$ and $60^{\circ}$ in the Northern Hemisphere [20]. The NPP/GPP ratios of Schleswig-Holstein for the years 2000, 2006 and 2012 matched these results, because that the land cover classes included in this study are typical land cover classes between $30^{\circ}$ and $60^{\circ}$ in the Northern Hemisphere.

The maps of the annual total GPP and the annual total NPP hotspots and cold spots indicated that the annual total GPP and the annual total NPP for the years 2000, 2006 and 2012 were not scattered randomly across Schleswig-Holstein but rather occurred in particular patterns (Fig. 11). The hotspots depict areas with high levels of the annual total GPP and the annual total NPP, and the cold spots present areas with low levels of the annual total GPP and the annual total NPP. However, the distributions of hotspots and cold spots are classified based on statistical values, their distributions indicate areas that have high or low value in one temporal-spatial condition [73]. The locations of the "pastures" that changed from 2000 to 2006, owing to crop rotation, matched to the hotspot loss of the annual total GPP and the annual total NPP from 2000 to 2006. The absent of "Complex cultivation patterns", which represented by elaborate cultivation areas, resulting in the hotspots loss of the annual total GPP and the annual total NPP from 2006 to 2012 due to the sharp area decline of "complex cultivation patterns" from 2006 until 2012. Enhancing the annual total GPP and the annual total NPP in western and eastern Schleswig-Holstein may increase the annual total stored GPP and the annual total stored NPP. Expending the land cover area of "pastures" and "complex cultivation patterns" is critical to increase the annual total stored GPP and the annual total stored NPP, which are representative of the ability of the landscape for fixing $\mathrm{CO}_{2}$.

Uncertainties originating from various inputs, such as land cover data, the fraction of the absorbed photosynthetic active radiation or the leaf area index, meteorological data, and the algorithm itself, can influence the accuracy of the GPP and NPP products [74, 75]. Furthermore, the annual total GPP and the annual total NPP distributions based on the CORINE land cover classes in our study were derived from the global estimation system with a resolution of $1 \mathrm{~km} \times 1 \mathrm{~km}$. The accuracy of the annual total GPP and the annual total NPP for some land cover classes with rare area may be deduced with the downscaling calculation from the global to the regional scale [76]. Considering the uncertainties in the regional assessments in Schleswig-Holstein, the recommended approach for managing uncertainties in the assessments is to collect high-quality and complete input data for the analysis. Furthermore, improving the estimation methodology for the annual total GPP and the annual total NPP is also important for uncertainty reduction. 


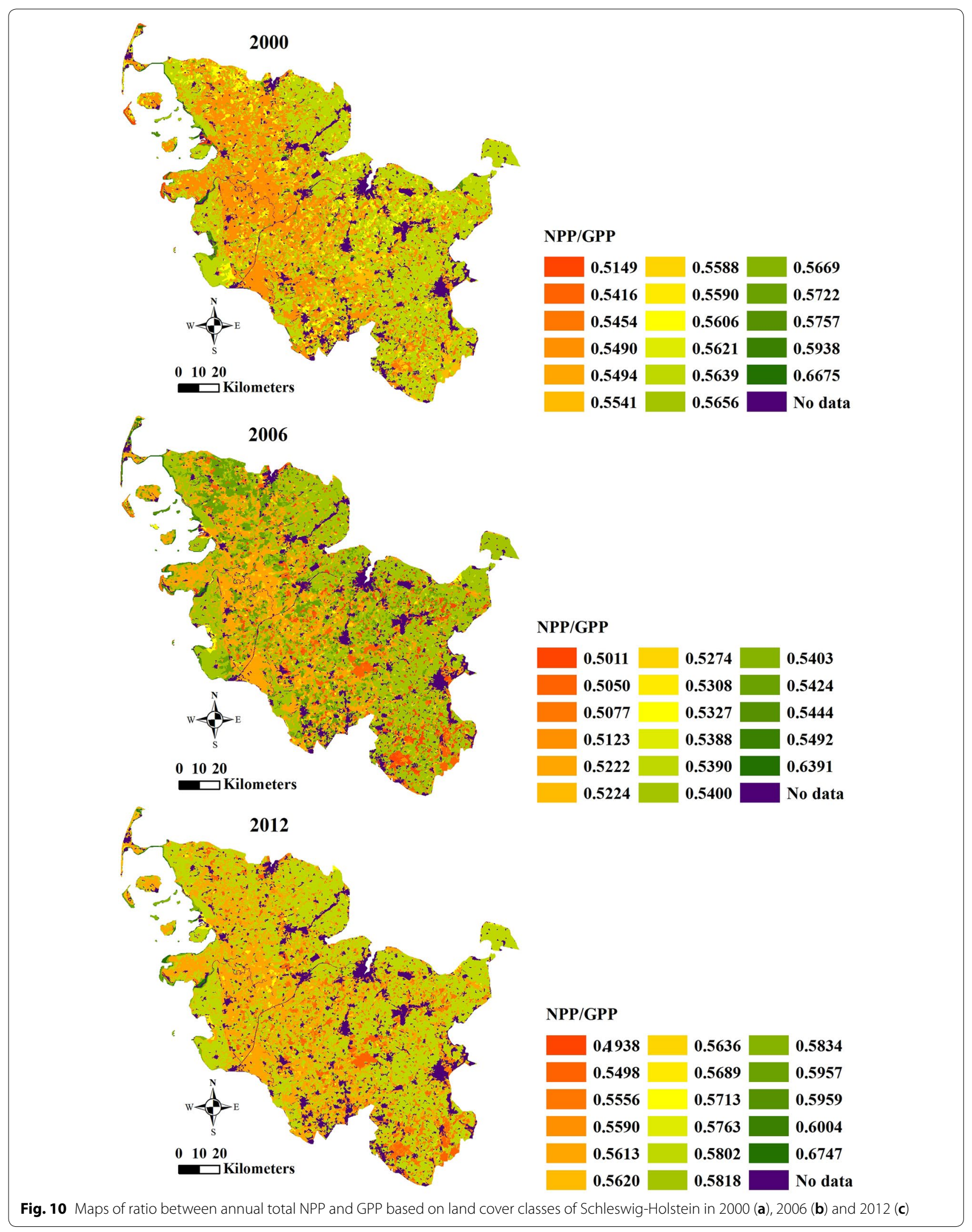




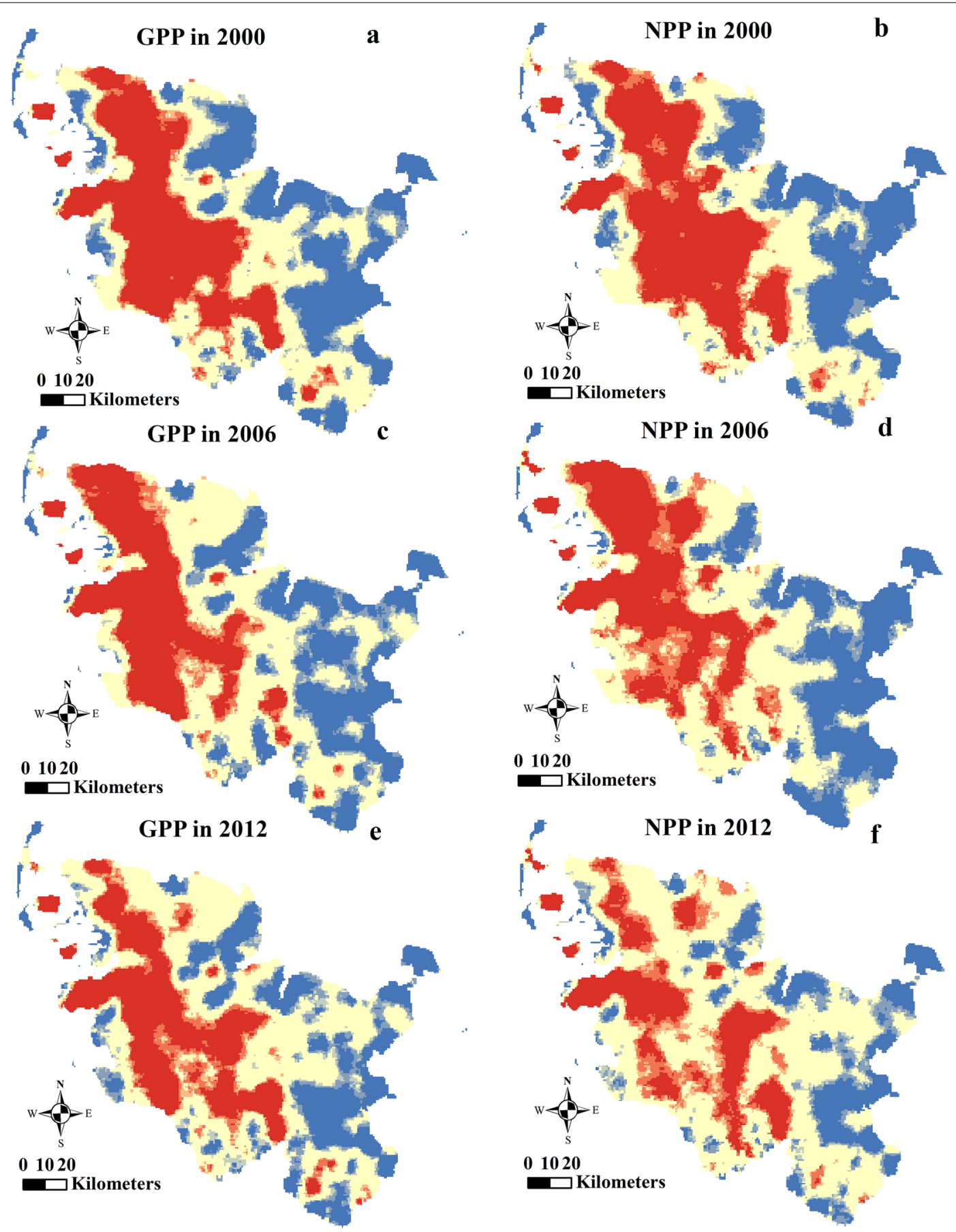

Lengend

Gi_Bin Not Significant

Cold Spot - 99\% Confidence Hot Spot - 90\% Confidence

Cold Spot - 95\% Confidence Hot Spot - 95\% Confidence

Cold Spot - 90\% Confidence - Hot Spot - 99\% Confidence

Fig. 11 Spatial distributions of hotspots and cold spots for annual total GPP (a, c and e) and NPP (b, d and f) of Schleswig-Holstein in 2000, 2006 and 2012 
Table 4 Calculated respiration and ratios between annual total NPP and GPP based on land cover classes of SchleswigHolstein in 2000, 2006 and 2012

\begin{tabular}{|c|c|c|c|c|c|c|}
\hline \multirow[t]{2}{*}{ Land cover classes } & \multicolumn{3}{|c|}{$\begin{array}{l}\text { Calculated respiration between GPP and NPP (GPP-NPP) (g C } \\
\mathrm{m}^{-2} \text { year }^{-1} \text { ) }\end{array}$} & \multicolumn{3}{|c|}{ Ratios between GPP and NPP (NPP/GPP) } \\
\hline & 2000 & 2006 & 2012 & 2000 & 2006 & 2012 \\
\hline $\begin{array}{l}\text { Non-irrigated arable } \\
\text { land }\end{array}$ & 474.38 & 469.53 & 434.64 & 0.5639 & 0.5400 & 0.5802 \\
\hline $\begin{array}{l}\text { Fruit trees and berry } \\
\text { plantations }\end{array}$ & 407.06 & 493.95 & 419.69 & 0.5938 & 0.5403 & 0.6004 \\
\hline Pastures & 556.73 & 543.87 & 500.84 & 0.5490 & 0.5222 & 0.5613 \\
\hline $\begin{array}{l}\text { Complex cultivation } \\
\text { patterns }\end{array}$ & 515.73 & 497.46 & 463.93 & 0.5606 & 0.5424 & 0.5818 \\
\hline $\begin{array}{l}\text { Land principally occu- } \\
\text { pied by agriculture }\end{array}$ & 500.31 & 485.46 & 446.70 & 0.5669 & 0.5388 & 0.5763 \\
\hline Broad-leaved forest & 546.76 & 550.42 & 500.68 & 0.5454 & 0.5011 & 0.5556 \\
\hline Coniferous forest & 555.75 & 563.34 & 529.20 & 0.5541 & 0.5050 & 0.5498 \\
\hline Mixed forest & 533.19 & 539.83 & 506.60 & 0.5588 & 0.5123 & 0.5590 \\
\hline Natural grasslands & 482.63 & 497.98 & 474.44 & 0.5757 & 0.5327 & 0.5713 \\
\hline Moors and heathland & 410.16 & 405.13 & 362.91 & 0.5621 & 0.5492 & 0.5620 \\
\hline $\begin{array}{l}\text { Transitional wood- } \\
\text { land-shrub }\end{array}$ & 504.84 & 503.82 & 393.62 & 0.5722 & 0.5390 & 0.5959 \\
\hline Beaches, dunes, sands & 273.87 & 132.92 & 101.56 & 0.5149 & 0.5077 & 0.5957 \\
\hline $\begin{array}{l}\text { Sparsely vegetated } \\
\text { areas }\end{array}$ & 373.31 & 367.05 & 435.57 & 0.5416 & 0.5308 & 0.4938 \\
\hline Inland marshes & 504.33 & 505.67 & 451.40 & 0.5590 & 0.5224 & 0.5689 \\
\hline Peat bogs & 551.21 & 521.19 & 483.17 & 0.5494 & 0.5274 & 0.5636 \\
\hline Salt marshes & 483.30 & 475.18 & 424.28 & 0.5656 & 0.5444 & 0.5834 \\
\hline Intertidal flats & 182.33 & 188.34 & 158.04 & 0.6675 & 0.6391 & 0.6747 \\
\hline
\end{tabular}

Table 5 Summary of the analysis for hotspot and cold spot areas of annual total GPP and NPP

\begin{tabular}{|c|c|c|c|c|c|c|c|c|}
\hline & \multirow[t]{2}{*}{ Year } & \multicolumn{7}{|c|}{ Area of hotspot and cold spot (ha) } \\
\hline & & $\begin{array}{l}\text { Cold } \\
\text { spot-99\% } \\
\text { confidence }\end{array}$ & $\begin{array}{l}\text { Cold } \\
\text { spot-95\% } \\
\text { confidence }\end{array}$ & $\begin{array}{l}\text { Cold } \\
\text { spot-90\% } \\
\text { confidence }\end{array}$ & $\begin{array}{l}\text { Not } \\
\text { significant }\end{array}$ & $\begin{array}{l}\text { Hotspot- } 90 \% \\
\text { confidence }\end{array}$ & $\begin{array}{l}\text { Hotspot-95\% } \\
\text { confidence }\end{array}$ & $\begin{array}{l}\text { Hotspot-99\% } \\
\text { confidence }\end{array}$ \\
\hline \multirow[t]{3}{*}{ GPP } & 2000 & 382,049 & 94,615 & 51,525 & 472,347 & 35,770 & 66,739 & 463,200 \\
\hline & 2006 & 359,810 & 113,410 & 56,736 & 524,258 & 43,768 & 73,461 & 394,801 \\
\hline & 2012 & 307,043 & 112,834 & 61,456 & 577,752 & 56,269 & 91,513 & 359,379 \\
\hline \multirow[t]{3}{*}{ NPP } & 2000 & 353,639 & 90,586 & 42,932 & 453,082 & 41,829 & 91,933 & 492,245 \\
\hline & 2006 & 352,170 & 95,339 & 40,060 & 482,294 & 59,269 & 141,421 & 395,691 \\
\hline & 2012 & 223,674 & 106,650 & 57,035 & 703,831 & 72,384 & 136,637 & 266,034 \\
\hline
\end{tabular}

\section{Conclusion}

In this study, for the years 2000, 2006 and 2012, the distributions of land cover classes based on the CORINE land cover data set, their influences on the GPP and NPP represented by the annual total GPP and the annual total NPP, the respiration and the NPP/GPP ratio based on the CORINE land cover classification, and the hotspots and cold spots of the respiration and the NPP/GPP ratios in Schleswig-Holstein were analyzed. The results presenting the land cover distributions in Schleswig-Holstein showed that "non-irrigated arable land", "pastures" and "complex cultivation patterns" were the dominant land cover classes for the years 2000 and 2006. "Non-irrigated arable land", "pastures" and "discontinuous urban fabric" occupied much more area than the other land cover classes in 2012. "Pastures" and "non-irrigated arable land" were the most widely distributed land cover classes in Schleswig-Holstein. 
The annual total GPP and NPP, the annual total stored GPP and NPP and the hotspots and cold spots of annual total GPP and NPP indicated the capacity of the carbon stocks in Schleswig-Holstein. The hotspots and cold spots of annual total GPP and NPP formed the adjacent significant areas with high annual total GPP and NPP, located from the central-western to the central-southern areas of Schleswig-Holstein. The cold spot areas with low annual total GPP and NPP were primarily located at the western edge and in the eastern part of the state. The calculated respiration in 2006 was higher than that in 2000 and 2012, and 2000 had the lowest respiration among the 3 years. The average ratios of the annual NPP/GPP were $0.5647,0.5350$ and 0.5573 in 2000, 2006 and 2012, respectively.

The findings reveal the carbon stocks in this area, as evaluated with the annual total GPP, the annual total NPP, the calculated respiration and the NPP/GPP ratio based on the CORINE land cover classes. Higher annual total stored GPP and NPP values mean more carbon fixation, and lower $\mathrm{CO}_{2}$ emissions. Hence, the land cover managers of Schleswig-Holstein can increase greenhouse gas fixation (e.g. $\mathrm{CO}_{2}$ ) by increasing the areas of "broadleaved forest", "coniferous forest", "mixed forest", "pastures" and "non-irrigated arable land".

\begin{abstract}
Abbreviations
GPP: Gross Primary Production; NPP: Net Primary Production; GIS: Geographic Information Systems; CS: Carbon stocks; EU: European Union; NPP/GPP: A ratio between GPP and NPP; EEA: European Environmental Agency; CORINE: Coordination of information on the environment; ATKIS: Amtliches Topographisch-Kartographisches Informations-System; CLC: CORINE land cover; CAP. Common agricultural policy; RES: Renewable energy sources.
\end{abstract}

\section{Acknowledgements}

I extend my thanks to the European Environmental Agency (EEA) and the Numerical Terradynamic Simulation Group of the University of Montana for the data sharing service system. The author thanks Prof. Dr. Felix Müller for his help in writing process. I am grateful for the time and efforts from the editors and the anonymous reviewers for helpful comments on a previous draft of the manuscript

\section{Authors' contributions}

LM analyzed and interpreted the data, and wrote the entire manuscript. The author read and approved the final manuscript.

\section{Funding}

This study was financially supported by the China Scholarship Council (Grant 201203270013).

\begin{abstract}
Availability of data and materials
The border maps of Germany and Schleswig-Holstein used in the current study are available in the ATKIS repository, https://www.adv-online.de/Produ cts/Geotopography/ATKIS/ (accessed 11 April 2013) [40]. CORINE land cover maps for Europe are available from https://land.copernicus.eu/pan-european/ corine-land-cover (accessed 20, May 2013) [36]. Gross Primary Production and Net Primary Production data are accessed from Project (MOD17) [44]. https:// files.ntsg.umt.edu/data/NTSG_Products/MOD17/ (accessed 17 August 2014).
\end{abstract}

Ethics approval and consent to participate

Not applicable.
Consent for publication

Not applicable.

\section{Competing interests}

The author has no competing interests.

\section{Author details}

${ }^{1}$ Department of Ecosystem Management, Institute for Natural Resource Conservation, Christian-Albrechts-Universität Zu Kiel, Olshausenstr.75, 24118 Kiel, Germany. ${ }^{2}$ Key Laboratory of Vegetation and Environmental Change, Institute of Botany, Chinese Academy of Sciences, 20 Nanxincun, Xiangshan, Beijing 100093, China.

Received: 16 August 2019 Accepted: 4 March 2020

Published online: 19 March 2020

\section{References:s}

1. Mauya EW, Mugasha WA, Njana MA, Zahabu E, Malimbwi R. Carbon stocks for different land cover types in Mainland Tanzania. Carbon Balance Manag. 2019;14(1):4. https://doi.org/10.1186/s13021-019-0120-1.

2. García-Llamas P, Geijzendorffer IR, García-Nieto AP, Calvo L, Suárez-Seoane S. Cramer W. Impact of land cover change on ecosystem service supply in mountain systems: a case study in the Cantabrian Mountains (NW of Spain). Reg Environ Change. 2019;19(2):529-42. https://doi.org/10.1007/ s10113-018-1419-2.

3. Göpel J, Schüngel J, Schaldach R, Meurer KHE, Jungkunst HF, Franko U, Boy J, Strey R, Strey S, Guggenberger G, Hampf A, Parker P. Future land use and land cover in Southern Amazonia and resulting greenhouse gas emissions from agricultural soils. Reg Environ Change. 2018;18(1):129-42. https://doi.org/10.1007/s10113-017-1235-0.

4. Kozak J, Gimmi U, Houet T, Bolliger J. Current practices and challenges for modelling past and future land use and land cover changes in mountainous regions. Reg Environ Change. 2017;17(8):2187-91. https://doi. org/10.1007/s10113-017-1217-2.

5. Ardli ER, Wolff M. Land use and land cover change affecting habitat distribution in the Segara Anakan lagoon, Java, Indonesia. Reg Environ Change. 2008;9(4):235. https://doi.org/10.1007/s10113-008-0072-6.

6. Torres R, Gasparri NI, Blendinger PG, Grau HR. Land-use and land-cover effects on regional biodiversity distribution in a subtropical dry forest: a hierarchical integrative multi-taxa study. Reg Environ Change. 2014;14(4):1549-61. https://doi.org/10.1007/s10113-014-0604-1.

7. Maes J, Egoh B, Willemen L, Liquete C, Vihervaara P, Schägner JP, Grizzetti B, Drakou EG, Notte AL, Zulian G, Bouraoui F, Luisa Paracchini M, Braat L, Bidoglio G. Mapping ecosystem services for policy support and decision making in the European Union. Ecosyst Serv. 2012;1 (1):31-9.

8. Olavson T, Fry C. Spreadsheet decision-support tools: lessons learned at Hewlett-Packard. Interfaces. 2008;38(4):300-10.

9. Grassi G, Cescatti A, Matthews R, Duveiller G, Camia A, Federici S, House J, de Noblet-Ducoudré N, Pilli R, Vizzarri M. On the realistic contribution of European forests to reach climate objectives. Carbon Balance Manag. 2019;14(1):8. https://doi.org/10.1186/s13021-019-0123-y.

10. Arowolo AO, Deng X. Land use/land cover change and statistical modelling of cultivated land change drivers in Nigeria. Reg Environ Change. 2018;18(1):247-59. https://doi.org/10.1007/s10113-017-1186-5.

11. Rosete Vergés FA, Velázquez A, Bocco G, Espejel I. Multi-scale land cover dynamics of semiarid scrubland in Baja California Mexico. Reg Environ Change. 2014;14(4):1315-28. https://doi.org/10.1007/s10113-013-0574-8.

12. Reichstein $M$, Bahn $M$, Ciais $P$, Frank $D$, Mahecha MD, Seneviratne SI, Zscheischler J, Beer C, Buchmann N, Frank DC, Papale D, Rammig A, Smith P, Thonicke K, van der Velde M, Vicca S, Walz A, Wattenbach M. Climate extremes and the carbon cycle. Nature. 2013;500(7462):287-95.

13. Kessel DG. Global warming — facts, assessment, countermeasures. J Petrol Sci Eng. 2000;26(1):157-68.

14. He Y, Piao S, Li X, Chen A, Qin D. Global patterns of vegetation carbon use efficiency and their climate drivers deduced from MODIS satellite data and process-based models. Agric For Meteorol. 2018;256:150-8.

15. Sinsabaugh RL, Moorhead DL, Xu X, Litvak ME. Plant, microbial and ecosystem carbon use efficiencies interact to stabilize microbial growth as a 
fraction of gross primary production. New Phytol. 2017;214(4):1518-26. https://doi.org/10.1111/nph.14485.

16. Chen $\mathrm{S}$, Jiang H, Cai Z, Zhou X, Peng C. The response of the net primary production of Moso bamboo forest to the on and off-year management: a case study in Anji County, Zhejiang. China For Ecol Manag. 2018:409:1-7.

17. Ma J, Yan X, Dong W, Chou J. Gross primary production of global forest ecosystems has been overestimated. Sci Rep. 2015;5:10820-10820. https ://doi.org/10.1038/srep10820.

18. De Lucia EH, Drake JE, Thomas RB, Gonzalez-Meler M. Forest carbon use efficiency: is respiration a constant fraction of gross primary production? Glob Change Biol. 2007;13(6):1157-67.

19. Goulden ML, McMillan AMS, Winston GC, Rocha AV, Manies KL, Harden JW, Bond-Lamberty BP. Patterns of NPP, GPP, respiration, and NEP during boreal forest succession. Glob Change Biol. 2011;17(2):855-71.

20. Zhang Y, Xu M, Chen H, Adams J. Global pattern of NPP to GPP ratio derived from MODIS data: effects of ecosystem type, geographical location and climate. Glob Ecol Biogeogr. 2009;18(3):280-90.

21. Yang Y, Wang Z, Li J, Gang C, Zhang Y, Odeh I, Qi J. Assessing the spatiotemporal dynamic of global grassland carbon use efficiency in response to climate change from 2000 to 2013. Acta Oecologica. 2017;81:22-31.

22. Feng X, Liu G, Chen JM, Chen M, Liu J, Ju WM, Sun R, Zhou W. Net primary productivity of China's terrestrial ecosystems from a process model driven by remote sensing. J Environ Manag. 2007;85(3):563-73.

23. Chen Z, Yu G, Zhu X, Wang Q, Niu S, Hu Z. Covariation between gross primary production and ecosystem respiration across space and the underlying mechanisms: a global synthesis. Agric For Meteorol. 2015;203:180-90.

24. Fennessy MS, Cronk JK. Primary production and respiration: ecological processes in Wetlands. In: Finlayson CM, Everard M, Irvine K, Mclnnes RJ, Middleton BA, van Dam AA, Davidson NC, editors. The Wetland book: I: structure and function, management and methods. Dordrecht: Springer; 2016. p. 1-8. ISBN 978-90-481-3493-9.

25. Gingrich S, Niedertscheider M, Kastner T, Haberl H, Cosor G, Krausmann F, Kuemmerle T, Müller D, Reith-Musel A, Jepsen MR, Vadineanu A, Erb K-H. Exploring long-term trends in land use change and aboveground human appropriation of net primary production in nine European countries. Land Use Policy. 2015;47:426-38.

26. Conant RT, Cerri CEP, Osborne BB, Paustian K. Grassland management impacts on soil carbon stocks: a new synthesis. Ecol Appl. 2017;27:662-8.

27. Turner DP, Ritts WD, Cohen WB, Gower ST, Zhao M, Running SW, Wofsy SC, Urbanski S, Dunn AL, Munger JW. Scaling Gross Primary Production (GPP) over boreal and deciduous forest landscapes in support of MODIS GPP product validation. Remote Sens Environ. 2003;88(3):256-70.

28. Wang P, Liu Y, Li L, Cheng K, Zheng J, Zhang X, Zheng J, Joseph S, Pan G. Long-term rice cultivation stabilizes soil organic carbon and promotes soil microbial activity in a salt marsh derived soil chronosequence. Sci Rep. 2015;5:15704-15704.

29. Alves MC, Carvalho LG, Oliveira MS. Terrestrial earth couple climate-carbon spatial variability and uncertainty. Glob Planet Change. 2013;111:930. https://doi.org/10.1016/j.gloplacha.2013.08.009.

30. El-Masri B, Barman R, Meiyappan P, Song Y, Liang M, Jain AK. Carbon dynamics in the Amazonian Basin: Integration of eddy covariance and ecophysiological data with a land surface model. Agric For Meteorol. 2013:182:156-67.

31. Zhao M, Heinsch FA, Nemani RR, Running SW. Improvements of the MODIS terrestrial gross and net primary production global data set. Remote Sens Environ. 2005;95(2):164-76.

32. Ma L, Bicking S, Müller F. Mapping and comparing ecosystem service indicators of global climate regulation in Schleswig-Holstein. Northern Germany Sci Total Environ. 2019;648(15):1582-97.

33. Liedtke H, Marcinek J. Physische geographie Deutschlands. Klett; 2002.

34. Stephan HJ. Schleswig-Holstein. In: Benda L, editors. Berlin: Klett, Bornträger, 1995.

35. CORINE land cover. CORINE land cover maps for Europe. 2012. https:// land.copernicus.eu/pan-european/corine-land-cover. Accessed 20 May 2013

36. Büttner G, Feranec J, Jaffrain G, Mari L, Maucha G, Soukup T. The Corine land cover 2000 project. The Corine land cover 2000 project 2004. p. 331-346. https://las.physik.uni-oldenburg.de/eProceedings/vol03 _3/03_3_buttner2.pdf. Accessed 19 May 2013.
37. Feranec J, Hazeu G, Christensen S, Jaffrain G. Corine land cover change detection in Europe (case studies of the Netherlands and Slovakia). Land Use Policy. 2007;24(1):234-47.

38. Schulp CJE, Burkhard B, Maes J, Van Vliet J, Verburg PH. Uncertainties in ecosystem service maps: a comparison on the European scale. PLoS ONE. 2014;9(10):1-11. https://doi.org/10.1371/journal.pone.0109643.

39. Atkis. Amtliches Topographisch-Kartographisches Informationssystem (ATKIS). 2013. https://www.adv-online.de/AAA-Modell/ATKIS/. Accessed 11 Apr 2013.

40. Justice CO, Vermote E, Townshend JRG, Defries R, Roy DP, Hall DK, Salomonson W, Privette JL, Riggs G, Strahler A, Lucht W, Myneni RB, Knyazikhin Y, Running SW, Nemani RR, Huete AR, van Leeuwen W, Wolfe RE, Giglio L, Muller J, Lewis P, Barnsley MJ. The Moderate Resolution Imaging Spectroradiometer (MODIS): land remote sensing for global change research. IEEE Trans Geosci Remote Sens. 1998;36(4):1228-499.

41. Shim C, Hong J, Hong J, Kim Y, Kang M, Malla Thakuri B, Kim Y, Chun J. Evaluation of MODIS GPP over a complex ecosystem in East Asia: a case study at Gwangneung flux tower in Korea. Adv Space Res. 2014;54(11):2296-308.

42. Justice CO, Townshend JRG, Vermote EF, Masuoka E, Wolfe RE, Saleous N, Roy DP, Morisette JT. An overview of MODIS land data processing and product status. Remote Sens Environ. 2002;83:3-15.

43. MODIS 17. MODIS GPP/NPP Project (MOD17). https://files.ntsg.umt.edu/ data/NTSG_Products/MOD17/. Accessed 17 Aug 2014.

44. Running SW, Zhao M. User's guide daily GPP and annual NPP (MOD17A2/ A3) products NASA earth observing system MODIS land algorithm. 2015. p. 1-28.

45. Friendly M. Corrgrams. Am Stat. 2002;56(4):316-24. https://doi. org/10.1198/000313002533.

46. Li G, Fang C, Wang S. Exploring spatiotemporal changes in ecosystemservice values and hotspots in China. Sci Total Environ. 2016;545:609-20.

47. The Esri Community. ArcGIS-ideas. 2016. https://community.esri.com/ community/arcgis-ideas/. Accessed 11 Jan 2013.

48. Cebecauer T, Hofierka J. The consequences of land-cover changes on soil erosion distribution in Slovakia. Geomorphology. 2008;98(3-4):187-98.

49. Munafò M, Salvati L, Zitti M. Estimating soil sealing rate at national levelItaly as a case study. Ecol Indic. 2013;26:137-40.

50. Ludwig R, Probeck M, Mauser W. Mesoscale water balance modelling in the Upper Danube watershed using sub-scale land cover information derived from NOAA-AVHRR imagery and GIS-techniques. Phys Chem Earth Parts A/B/C. 2003;28(33-36):1351-64.

51. Kruse M, Dörnhöfer K, Oppelt N, Müller F. Detecting land use and land cover changes in Northern German agricultural landscapes to assess ecosystem service dynamics. Landscape Online 2014;35(1):1-24.

52. Keil M, Esch T, Divanis A, Marconcini M, Metz A, Ottinger M, Voinov S, Wiesner M, Wurm M. Updating the land use and land cover database CLC for the year 2012-"backdating" of DLM-DE from the reference year 2009 to the year 2006. Dessau-Roßlau. 2014.

53. Kandziora M, Burkhard B, Müller F. Interactions of ecosystem properties, ecosystem integrity and ecosystem service indicators: a theoretical matrix exercise. Ecol Ind. 2013;28:54-78.

54. Wördehoff R, Spellmann H, Evers J, Aydın CT, Nagel J. Kohlenstoffstudie Forst und Holz Schleswig-Holstein. Nordwestdeutsche Forstliche Versuchsanstalt, Eigenverlag, Göttingen 2012. https://www.schleswig-holst ein.de/UmweltLandwirtschaft/DE/NaturschutzForstJagd/06_Wald/022_ Kohlenstoffstudie/PDF/Kohlenstoffstudie_blob=publicationFile.pdf. Accessed 25 Oct 2014.

55. Rounsevell MDA, Audsley E, Mortimer D. The impact of the common atricultural policy on land use in europe. Land Use Land Cover Soil Sci. 2000:4:1-26.

56. Feranec J, Jaffrain G, Soukup T, Hazeu G. Determining changes and flows in European landscapes 1990-2000 using CORINE land cover data. Appl Geogr. 2010;30(1):19-35. https://doi.org/10.1016/j.apgeog.2009.07.003.

57. Li W, Ciais P, Peng S, Yue C, Wang Y, Thurner M, Saatchi SS, Arneth A, Avitabile V, Carvalhais N, Harper AB, Kato E, Koven C, Liu YY, Nabel JEMS, Pan Y, Pongratz J, Poulter B, Pugh TAM, Santoro M, Sitch S, Stocker BD, Viovy $\mathrm{N}$, Wiltshire A, Yousefpour R, Zaehle S. Land-use and land-cover change carbon emissions between 1901 and 2012 constrained by biomass observations. 2017. 
58. Wadduwage S, Millington A, Crossman ND, Sandhu H. Agricultural land fragmentation at urban fringes: an application of urban-to-rural gradient analysis in Adelaide. Land. 2017;6(2):28.

59. Strunz $S$. The German energy transition as a regime shift. Ecol Econ. 2014;100:150-8.

60. Felten D, Fröba N, Fries J, Emmerling C. Energy balances and greenhouse gas-mitigation potentials of bioenergy cropping systems (Miscanthus, rapeseed, and maize) based on farming conditions in Western Germany. Renew Energy. 2013;55:160-74.

61. Schleswig-Holstein SAfHu. Statistisches Jahrbuch Schleswig-Holstein 2005/2006. Hamburg. 2006.

62. Baumann FM. Biomass and bioenergy in Germany and the state of North Rhine-Westphalia. 2014. p. 1-26.

63. Kauffman JB, Arifanti VB, Bernardino AF, Ferreira TO, Murdiyarso D, Cifuentes M, Norfolk J. And details for land-use carbon footprints arise from quantitative and replicated studies. Front Ecol Environ. 2018;16(1):12-3. https://doi.org/10.1002/fee.1749.

64. Marques A, Martins IS, Kastner T, Plutzar C, Theurl MC, Eisenmenger N, Huijbregts MAJ, Wood R, Stadler K, Bruckner M, Canelas J, Hilbers JP, Tukker A, Erb K, Pereira HM. Increasing impacts of land use on biodiversity and carbon sequestration driven by population and economic growth. Nat Ecol Evol. 2019;3(4):628-37. https://doi.org/10.1038/s4155 9-019-0824-3.

65. Lavigne F, Gunnell Y. Land cover change and abrupt environmental impacts on Javan volcanoes, Indonesia: a long-term perspective on recent events. Reg Environ Change. 2006;6(1):86-100. https://doi. org/10.1007/s10113-005-0009-2.

66. Pachauri RK, Meyer L. Climate change 2014. Synthesis Report. 2014. p. 133

67. Arneth A, Sitch S, Pongratz J, Stocker BD, Ciais P, Poulter B, Bayer AD, Bondeau A, Calle L, Chini LP, Gasser T, Fader M, Friedlingstein P, Kato E, Li W, Lindeskog M, Nabel JEMS, Pugh TAM, Robertson E, Viovy N, Yue C, Zaehle S. Historical carbon dioxide emissions caused by land-use changes are possibly larger than assumed. Nat Geosci. 2017;10:79. https://doi. org/10.1038/ngeo2882.
68. Wang X, Wiegand T, Wolf A, Howe R, Davies SJ, Hao Z. Spatial patterns of tree species richness in two temperate forests. J Ecol. 2011;99(6):1382-93. https://doi.org/10.1111/j.1365-2745.2011.01857.x.

69. Kramberger B, Gselman A, Kristl J, Lešnik $M$, Šuštar V, Muršec M, Podvršnik M. Winter cover crop: the effects of grass-clover mixture proportion and biomass management on maize and the apparent residual $\mathrm{N}$ in the soil. Eur J Agron. 2014;55:63-71.

70. Liu W, Zhang G, Wang X, Lu F, Ouyang Z. Carbon footprint of main crop production in China: magnitude, spatial-temporal pattern and attribution. Sci Total Environ. 2018;645:1296-308.

71. Hou Y, Zhou S, Burkhard B, Müller F. Socioeconomic influences on biodiversity, ecosystem services and human well-being: a quantitative application of the DPSIR model in Jiangsu. China Sci Total Environ. 2014;490:1012-28.

72. Zhang Y, Huang K, Zhang T, Zhu J, Di Y. Soil nutrient availability regulated global carbon use efficiency. Glob Planet Change. 2019;173:47-52.

73. Plieninger T, Dijks S, Oteros-Rozas E, Bieling C. Assessing, mapping, and quantifying cultural ecosystem services at community level. Land Use Policy. 2013;33:118-29.

74. Lang M, Kõlli R, Nikopensius M, Nilson T, Neumann M, Moreno A. Assessment of MODIS NPP algorithm-based estimates using soil fertility and forest inventory data in mixed hemiboreal forests. For Stud. 2017;66:49-644.

75. Zhao M, Running SW, Nemani RR. Sensitivity of Moderate Resolution Imaging Spectroradiometer (MODIS) terrestrial primary production to the accuracy of meteorological reanalyses. J Geophys Res Biogeosci. 2006;111(1):1-13. https://doi.org/10.1029/2004JG000004.

76. Hou Y, Burkhard B, Müller F. Uncertainties in landscape analysis and ecosystem service assessment. J Environ Manag. 2013;127:S117-S13131.

\section{Publisher's Note}

Springer Nature remains neutral with regard to jurisdictional claims in published maps and institutional affiliations.
Ready to submit your research? Choose BMC and benefit from:

- fast, convenient online submission

- thorough peer review by experienced researchers in your field

- rapid publication on acceptance

- support for research data, including large and complex data types

- gold Open Access which fosters wider collaboration and increased citations

- maximum visibility for your research: over 100M website views per year

At BMC, research is always in progress.

Learn more biomedcentral.com/submissions 